\title{
OMPARATIVE ANALYSIS OF BIRDLIFE IN DIFFERENT ECOLOGICAL RESTORATION METHODS WITH EMPHASIS ON THE ROLE OF ARTIFICIAL PERCHES
}

\author{
Huilquer Francisco Vogel \\ Universidade Estadual do Paraná (UNESPAR), Campus União da Vitória, Paraná, Brasil. \\ E-mail: huilquer@hotmail.com
}

\section{João Batista Campos}

Secretaria de Estado de Meio Ambiente e Recursos Hídricos (SEMA), Coordenadoria de Biodiversidade e Florestas, Curitiba, Paraná, Brasil. E-mail: joaobatista@iap.pr.gov.br

\section{KIMBERLY S. SHELDON}

Department of Ecology \& Evolutionary Biology at the University of Tennessee, Knoxville, USA. E-mail: ksheldon@utk.edu

\section{Fernando Campanhã Bechara}

Universidade Tecnológica Federal do Paraná (UTFPR), Campus Dois Vizinhos, Laboratório de Ecologia e Taxonomia Florestal, Paraná, Brasil. E-mail: bechara@utfpr.edu.br

\begin{abstract}
Artificial perches provide complexity to the landscape, a factor that can increase animal biodiversity. We tested the hypothesis that artificial perches used in ecological restoration promote increased birdlife diversity in a restored landscape in southern Brazil. The study was conducted in the southwest of Paraná State, on land used for years for agriculture and pasture. Estimates of species and diversity of avifauna in 12 experimental plots were obtained one year after the beginning of the restoration. Data from plots restored through nucleation, which consisted of inserting artificial perches, were used to create a data set analyzed with and without the records of birds obtained exclusively on artificial perches. These data were compared with those from experimental plots re-vegetated by either passive or active (i.e. high diversity planting) restoration. In addition, the ability of different restoration techniques to attract avifauna occurring in a nearby forest was investigated. Restored plots using nucleation had higher richness (42 \pm 3.00 SD species), abundance and diversity compared to passive restoration and high diversity planting. However, when the results obtained exclusively from artificial perches were disregarded, the pattern of the diversity components in the nucleation did not differ from that of the passive restoration. Thus, the artificial perches provided an additional niche and, in this study, represented $34 \%$ of the increase in the accumulated richness observed in nucleation. Thus, perches are an important natural engineering structure that can increase local bird richness.
\end{abstract}

Keywords: Atlantic rain forest, ecological succession, neotropical birds, restoration ecology.

\section{A ANÁlise Comparativa da AVIFAUNA EM difERENTES MÉtodos de RESTAURAÇÃo ECOLÓgICA COM ÊNFASE NO PAPEL DE POLEIROS ARTIFICIAIS}

Resumo: Os poleiros artificiais proporcionam complexidade à paisagem, um fator que pode aumentar a biodiversidade. Testamos a hipótese de que os poleiros artificiais utilizados na restauração ecológica são fatores que promovem riqueza específica de aves em uma paisagem restaurada no sul do Brasil. O estudo foi realizado no sudoeste do estado do Paraná, em uma área que serviu durante anos para 
a agricultura e pastagem. Estimativas das espécies e da diversidade da avifauna foram obtidas em 12 parcelas experimentais um ano após o início da restauração. Dados de parcelas restauradas por meio da nucleação (este método consiste também em inserir poleiros artificiais) foram utilizados para criar um conjunto de dados analisados com e sem registros de aves obtidas exclusivamente em poleiros artificiais. Esses dados foram comparados com os de parcelas experimentais revegetadas por restauração passiva ou ativa (plantação de alta diversidade). Além disso, investigamos a capacidade de diferentes técnicas de restauração para atrair avifauna ocorrendo em uma floresta próxima. As parcelas restauradas com nucleação apresentaram maior riqueza (42 $\pm 3,00 \mathrm{DP}$ espécies), abundância e diversidade em relação à restauração passiva e plantio de alta diversidade. No entanto, quando os resultados obtidos exclusivamente a partir de poleiros artificiais foram desconsiderados, o padrão dos componentes de diversidade na nucleação não diferiu do modelo da restauração passiva. Os poleiros artificiais forneceram um nicho adicional e, neste estudo, representaram $34 \%$ do aumento da riqueza acumulada observada no tratamento de nucleação. Desse modo, poleiros são importantes estruturas de engenharia natural que causa aumento local da riqueza de aves.

Palavras-chave: Mata Atlântica, sucessão ecológica, aves neotropicais, ecologia da restauração.

\section{INTRODUCTION}

The abandonment of pastures and croplands permits environmental colonization by diverse bird species, whose roles were previously limited to agroecosystem pioneer species (Fuller et al., 2001). This process occurs because constant changes are promoted by livestock and agricultural management (Haslem \& Bennett, 2008). Thus, changes in the structure of agricultural landscapes promote direct alterations in the composition of bird assemblages (Báldi \& Bátari, 2011; Sanderson et al., 2013). This process is dynamic, influenced by the distance between the forest fragments (Akçakaya et al., 2007) and by the size and quality of the new habitat patch (Fink et al., 2009).

Some birds are associated with certain phases of forest regeneration. They are mobile in the landscape, rapidly colonizing environments in the initial process of regeneration (Schieck \& Song, 2006). These species later disappear or are replaced during ecological succession (Odum, 1950).

Other birds are adapted to more stable environments and depend on the integrity of primary forests (Anjos, 2006). Thus, there is a very dynamic alternation of ecological release, followed by a competitive increase within each phase of ecological succession, causing cycles of new coIonization and local extinctions (Wright, 1980; Anjos, 2004).

Recently restored environments can serve as partial or temporary habitats, decreasing the competition for resources within adjacent forests (Esler, 2000; Akçakaya et al., 2007). Thus, ecological restoration creates new forest niches, which gradually appear in the landscape. Using this mechanism, birds occurring in stable areas gradually colonize restored environments, increasing their similarity to nearby forests in terms of faunistic composition (Reid et al., 2012).

Diverse strategies have been used to increase the speed of ecological restoration, such as ap- plied nucleation (Reis et al., 2010; Corbin \& Holl, 2012). This technique utilizes a set of procedures involving planting trees in nuclei, the use of shelters for fauna, artificial perches for avifauna, planting of seed banks and seed rain, and the use of living mulch in nuclei. These procedures are based on the facilitation mechanism that favors the arrival and establishment of new species of flora and fauna in the habitat (Yarranton \& Morrison, 1974; Reis et al., 2003).

Applied nucleation is an alternative to the conventional planting of pure and mixed tree species (Jordan et al., 2003; Corbin \& Holl, 2012; Van-Andel \& Aronson, 2012; Zahawi et al., 2013). In the same way, plantations of native species are an appropriate choice, because they allow the insertion of elevated floristic richness, which attracts animals (Wunderle-Jr., 1997; Rodrigues et al., 2011). However, in certain situations, they can present low structural complexity, because they are characteristic of more senescent forests (Brady \& Noske, 2010).

One of the more relevant techniques for attracting birds to recently restored areas is the use of artificial or natural perches (Verdu \& Garcia-Fayos, 1996). In nature, birds use dry trees as perches to observe prey, perform courtship and mating displays, eat insects inhabiting the bark and wood, or to rest between forest fragments (Holl, 1998; Bocchese et al., 2008; Ortega-Alvarez \& Cisneros, 2012). Artificial bird perches can also act as hunting and resting areas for some hawk and owl species that prey on animals that can jeopardize the restoration and thus decrease their incidence (Hall et al., 1981; Pias et al., 2012). In addition, perches attract birds that feed on fruit, contributing to zoochorous dispersal of seeds of woody plants (Shiels \& Walker, 2003; Graham \& Page, 2012).

Many bird species possess a clear preference for perches (Holl, 1998; Guedes et al., 2006; Vi- 
cente et al., 2010). These perches, in turn, can lead to an increase in the architecture of the environment (structural complexity), which increases the number of available niches (Willson, 1974; Hulbert, 2004; Horgan et al., 2016). Thus, theoretically, artificial perches can increase the structural complexity of the landscape (McDonnel \& Stiles, 1983; Pillatt et al., 2010; Horgan et al., 2016), favoring an increase in the local richness of the bird assemblage.

We hypothesized that artificial perches used in nucleation are crucial for promoting richness in the assemblage of birds that initially recolonize altered habitats. Moreover, we compared the richness, abundance, and diversity of birds that occur in restored habitats, using different restoration techniques. During the first 2 years of restoration, we tested (a) the effect of artificial perches used in habitats restored under nucleation in relation to the total variation of the richness, abundance, and diversity of the assemblage; (b) the preference of different guilds in relation to the treatments and experimental groups; and (c) the capacity of the restoration techniques used in the service of a partial habitat for birds that occurred in a nearby forest fragment, which theoretically functions as a source area of species for restored plots.

\section{Materials ANd Methods}

\section{STUDY AREA}

The experiment was conducted on the area adjacent to a legal reserve of the campus of Federal Technological University of Paraná ( $p t$. ., UTFPR) in the municipality of Dois Vizinhos, state of Paraná, Brazil, Fig. 1. The region is an ecotone between a "Mixed Ombrophilous Forest" or Araucaria Moist Forest, and the "Seasonal Semideciduous Forest" or Alto Paraná Forest. The area is categorized as transitional in two climate zones: $C f b$ and $C f c$ from the Köppen climate classification system. The altitude is approximately 500 $\mathrm{m}$ and the amount of annual rainfall is approximately 1,800-2,000 $\mathrm{mm}$ (Gerber et al., 2017). Latosolos (Oxisols; $\mathrm{Bw}$ ) predominate the site, which are generally deep and historically used in successive plantings.

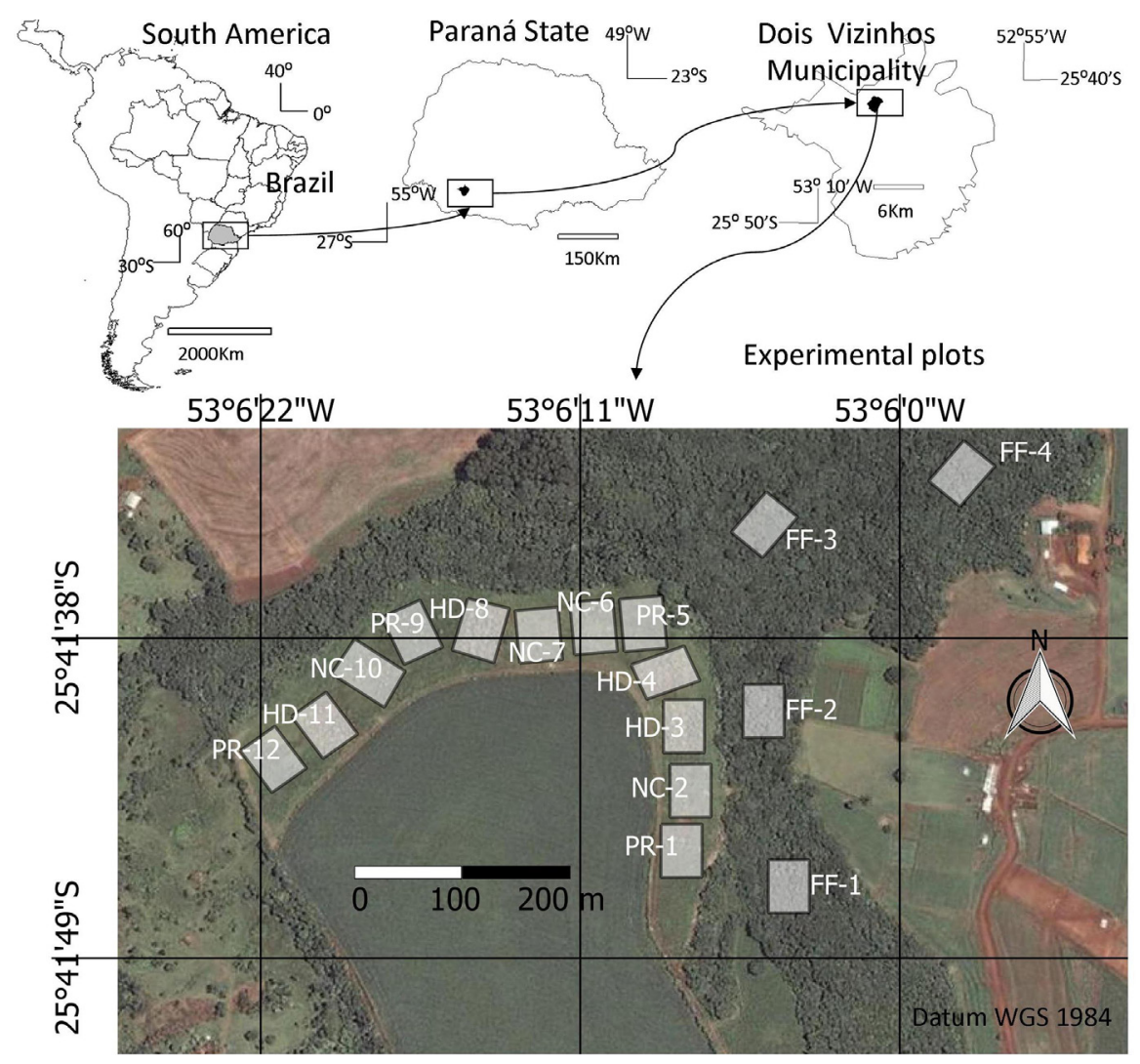

Fig. 1. Map indicating the location of the study area and experimental plots. Characteristics of the landscape, containing nucleation (NC), passive restoration (PR), and high-diversity planting (HD) and plots in the forest fragment (FF) that borders the experimental area can be observed. Adapted from Google Earth (2015). 
Between 1993 and 2005, wheat and oats were cultivated in winter, while corn, soybeans, and kidney beans were cultivated in summer. The site was used as pasture between 2006 and 2008. To this end, forage species such as African Bermuda-grass (Cynodon nlemfuensis), Guinea grass (Megathyrsus maximus), and Signal grass (Brachiaria decumbens) were inserted. In 2010, there were annual cultures until the last harvest of the year (October).

\section{EXPERIMENTAL DESIGN}

The experiment (Fig. 1) was designed by F.C.B and arranged in 12 randomly distributed plots $(40 \times 54 \mathrm{~m})$. Each treatment included four replications, totaling $8.640 \mathrm{~m}^{2}$ or 0.86 hectares. The treatments were nucleation (NC), passive restoration (PR), and high-diversity planting (HD), an active restoration methodology. The plots were arranged $13 \pm 5 \mathrm{~m}$ ( \pm SD - standard deviation) apart and $20.6 \pm 5.7 \mathrm{~m}$ from the nearby forest fragment, whose boundaries were clearly indicated by wooden rods. In October 2010, the whole area was cleared using a lawn tractor, initiating soil preparation. In December, seedlings began to be planted.

\section{ECOLOGICAL RESTORATION TECHNIQUES}

The general planting procedures (to NC, PA, and $\mathrm{HP}$ ) involved harrowing of the soil to a depth of about $5 \mathrm{~cm}$. In December 2010, holes were manually opened to a depth of $20 \mathrm{~cm}$ and formicide baits were arranged in traps surrounding the experimental area. In NC, seven nucleation techniques were used, adapted from previous studies (Reis et al., 2010; Bechara et al., 2016), in six $3 \times 40 \mathrm{~m}$ strips per plot, occupying $33.33 \%$ of the total area. Two structural and five procedural techniques were used in each plot (Fig. 2a). The structural techniques consisted of: (1) use of a stereometric volume $(1 \times 1 \times 1 \mathrm{~m}$ woodpile $)$ for the fauna; (2) two artificial perches (10 m high and mean diameter between 15 and $20 \mathrm{~cm}$ ), made from dry trunks of eucalyptus (Eucalyptus grandis). The winged-stem passion fruit (Passiflora alata) was cultivated at the base of each perch, as described by Reis et al. (2003).

The five procedural techniques included: (3) six seed banks (area: $1 \mathrm{~m}^{2}$; depth: $10 \mathrm{~cm}$ ), which were collected in natura, deposited in trays, and cultivated in nurseries. The seedlings that germinated were later transferred to the field. Six 1 $\mathrm{m}^{2}$ blocks of seed rain per plot were also inserted (4). The seed rain was obtained by means of 30 collectors (area: $1 \mathrm{~m}^{2}$ ). The material obtained from the collectors was homogenized and cultivated in nurseries.

The seedlings, as well as ungerminated seeds, were later transferred to the field. The seed bank and seed rain were obtained in a secondary forest remainder $\left(25^{\circ} 36^{\prime} 22^{\prime \prime} \mathrm{S} ; 5^{\circ} 48^{\prime} .20^{\prime \prime} \mathrm{W}\right)$ with the objective of potentiating natural regeneration with local species. In order to attract pollinators that can serve as food for the fauna in restored areas (Golawski \& Golawska, 2013), as well as to increase the biomass of the soil (Beltrame \& Rodrigues, 2008), the pigeon pea Cajanus cajan (5) was sown in 12 nuclei with $3 \times 4$ m nuclei, with six rows and a density of approximately 20 seeds per linear meter.

In total, 24 densely vegetated nuclei were planted. They were composed of five seedlings (6), which were planted $1 \mathrm{~m}$ apart and arranged in a "+" form. There were four rapid-growth pioneer seedlings at the edges, and one shaded non-pioneer species in the center, as described by Anderson (1953). In total, 12 pioneer species and 24 non-pioneer species were used. They are listed in Annex 1 (556 seedlings ha ${ }^{-1}$ ). Finally, (7) six groups of bromeliads "caraguatá" (Bromelia antiacantha) were inserted in nuclei with five seedlings, $0.5 \mathrm{~m}$ apart, and arranged in a " + " form (Anderson, 1953). 


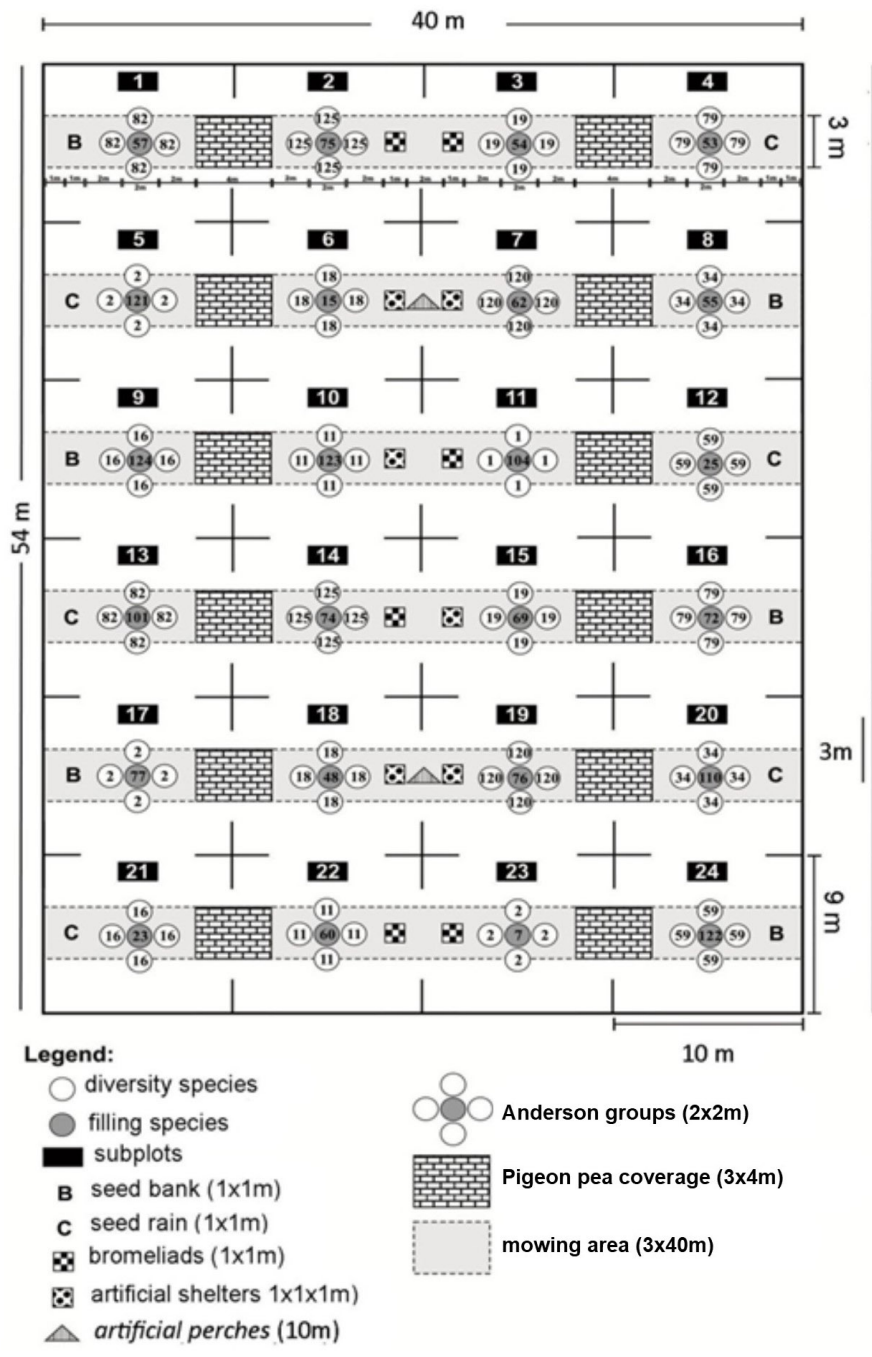

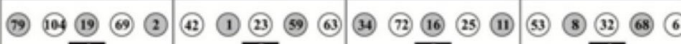

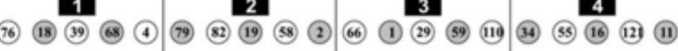

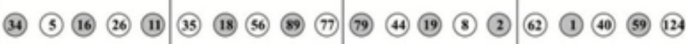

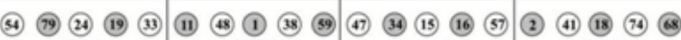

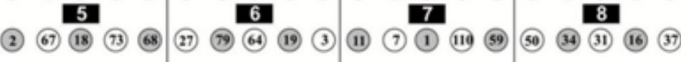

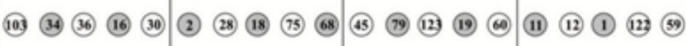

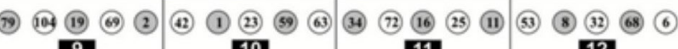
(76) (18) (39) (3) (4) (79) (82) (19) (3) (3) (66) (1) (39) (59) (111) (34) (55) (16) (12) (11)

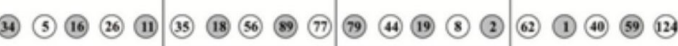

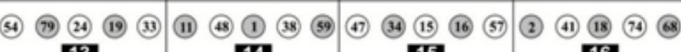
131514

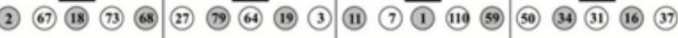

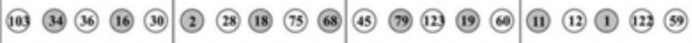

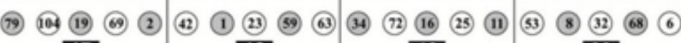
17150

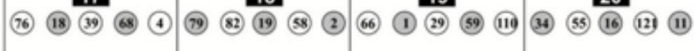

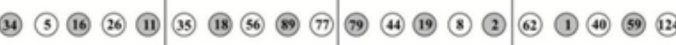

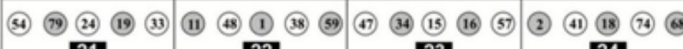

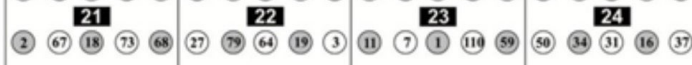

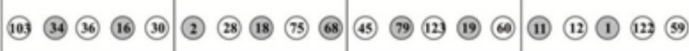
$\overline{2 m}$

Fig. 2. Experimental design used in the nucleation (a) and the high-diversity planting (b). The numbers correspond to the species described in supplementary document 1. Adapted from a previous study (Vogel et al., 2015).

The passive restoration treatment (PR) had a dual function. In addition to the treatment, it was also used as a local control, because a natural regeneration area with the same age as the other treatments is necessary for comparison. Since the perimeter had been delimited, the area was only protected against disturbances such as fire and grazing (Shono et al., 2007; Rey-Banayas et al., 2008).

High-diversity tree planting (HD) was based on the technique of fillings and diversity lines (Gonçalves et al., 2005; Gandolfi et al., 2007; Rodrigues et al., 2009, 2011). In total, 70 regional tree species were used (supplementary document 1), of which 10 were pioneer (filling) and 60 non-pioneer (diversity; secondary and climax) species. The seedlings were inserted in the field at heights varying between 20 and $35 \mathrm{~cm}$, systematically alternating filling and diversity species (Fig. 2b).
Regarding NC and $\mathrm{HD}$, quarterly mowing was carried out, starting from the implementation date, and seedlings were weeded using glyphosate ${ }^{\circledR}$. In $H D$, the lianas and herbaceous vegetation was totally removed, leaving the soil exposed, and the vegetation was introduced by planting. In NC, management by mowing occurred with the same periodicity as in $\mathrm{HD}$, only in the six $3 \times 40$ $\mathrm{m}$ strips per plot $(33.33 \%$ ) of the total area (only where the techniques were inserted). To implant the five procedural techniques in NC and seedlings in plots in the forest fragment (FF), chemical fertilizer (NPK: 05-20-10, dose: $30 \mathrm{~kg} / \mathrm{ha}$ of N; $120 \mathrm{~kg} / \mathrm{ha}$ of $\mathrm{P}_{2} \mathrm{O} 5 ; 60 \mathrm{~kg} / \mathrm{ha}$ of $\mathrm{K}_{2} \mathrm{O}$ ) was used. The woody species used are detailed in supplementary document 1 .

Part of the vegetation in the fragment has been removed, with disturbances ceasing approximately 30 years ago. At that time, about 1 ha 
of loblolly pine (Pinus taeda), 0.5 ha of Camden white gum (Eucalyptus benthamii), and 0.5 ha of Japanese raisin tree (Hovenia dulcis) had been inserted. The fragment is in the initial/middle secondary stage of regeneration, isolated by an agroecosystematic matrix composed of pastures and plantations. The species with the 10 highest importance values (IV) formed $78 \%$ of the total value; for example, Matayba elaeagnoides, Luehea divaricata, Sebastiania commersoniana, H. dulcis, Parapiptadenia rigida, Nectandra lanceolata, Ocotea puberula, Casearia decandra, and Campomanesia xanthocarpa (Gorenstein et al., 2011).

\section{DATA COLLECTION}

Twenty-four samplings (six per season) were carried out from January to December 2012, with a sampling effort of eight hours per plot or 96 hours during the whole experiment. The bird census was conducted 1 year after the beginning of the restoration, with richness and abundance determined by directly counting the individuals by means of a single sampling point in the center of each experimental plot (Bibby et al., 2000). However, only records of birds perched were considered. Sampling was performed every 15 days; nevertheless, some observations were postponed due to adverse weather conditions (i.e. rain and wind). As far as possible, sampling was standardized and carried out on sunny days or days with light rain ( $<5 \mathrm{~mm} /$ day).

Each sampling lasted 20 min (10 in the morning and 10 in the afternoon). The census started when the sun was at an angle of approximately $5^{\circ}$ on the horizon ( $\sim 06 \mathrm{~h} 30 \mathrm{~s}$ to $\sim 08 \mathrm{~h} 40 \mathrm{~s},-3 \mathrm{GMT})$. In the afternoon, the sun was at $45^{\circ}(\sim 16 \mathrm{~h} 30 \mathrm{~s}$ to $\sim 18 \mathrm{~h} 30 \mathrm{~s}$ ). This design was chosen because 20 consecutive minutes would greatly increase the chance of resampling the same individuals. Dividing the 20 min into two 10 min periods can also lead to an overestimation of abundance; however, it increases the chance of detecting discrete species (Vielliard et al., 2010).

The starting plot was randomly assigned, and the trajectory was always from the first to the last plot $(1 \rightarrow 12)$. In the adjacent forest fragment, four equidistant (approximately $150 \mathrm{~m}$ ) listening points (Anjos, 2007) were used, using colored tags as markers, distributed on the observation perimeter to match the sampling area of the experimental plots, with the same sampling procedures carried out in the experimental plots and sampling direction $(1 \rightarrow 4)$. The nomenclature used to identify birds was consistent with the Brazilian Committee of Ornithological Records (Piancintini et al., 2015).

\section{DATA ANALYSIS}

Regarding the plots restored by nucleation, the records obtained from the artificial perches were separated from the rest of the data (soil + vegetation), creating the artificial group NC-AP. Conversely, a second group containing only the records obtained from the artificial perches (AP) was created. This design was selected to determine the contribution of the birds to the component parameters of diversity, allowing the free possibility of the birds occupying both the perches and the vegetation/soil, which would not be possible in treatments that had a design with and without perches. Four treatments (FF, NC, PR, and HD) and two artificial groups (NC-AP and AP) were dealt with. Of note, FF was not specifically a treatment, but a species source area. However, it was interpreted as a treatment for analytical purposes.

Species richness estimates (Jackknife 1 and Chao 2) were obtained for each treatment and artificial group, as well as the collector's curve, using observed richness, Sobs - Mao Tau with 10,000 permutations (Colwell et al., 2004). To this end, the software Stimates ${ }^{\circledR}$ was used (Colwell, 2011). Further, with observed abundance (N) and richness (S) as a base, the Shannon-Weaver in$\operatorname{dex}\left(\mathrm{H}^{\prime}\right)$ and the Pielou uniformity index $\left(\mathrm{J}^{\prime}\right)$ were estimated for each sample (Krebs, 1999).

To obtain evidence to support the hypothesis, the mean values of the richness, abundance, and diversity parameters were obtained in each sampling were submitted to an analysis of variance (two-way ANOVA) with six groups [(FF, NC, PR, and HD) and two artificial groups (NC-AP and AP)]. The plots were pseudoreplicates and the 24 samplings were repetitions. A post hoc Tukey test was then carried out. To evaluate the presuppositions of the analysis, the Shapiro-Wilk test for normality and the Bartlett test for homogeneity of the variances were used (Quinn \& Keough, 2002). Data were analyzed using the program Statistica 7.0 (Statsoft INC., 2004).

To complement the interpretation of the role of artificial perches as an additional niche in NC, an ordination of the experimental plots and the groups was carried out. These data were ordered by means of principal components analysis (PCA), using the broken-stick criterion to reduce the axes to be interpreted (Johnson \& Wichern, 2007). Berger-Parker - D dominance values were used as quantitative variables (Melo, 2008), and were obtained from the total contacts of each species per plot. The scores of the axes between treatments were later tested using the Kruskal-Wallis-KW ${ }^{2}$ non-parametric variance analysis (Corder and Foreman, 2009). These tests were performed using the computational tools Pc-Or$\mathrm{dtm}$ ver. 6 (McCune \& Mefford, 2011) and PAST ${ }^{\circledR}$ ver. 2.17 (Hammer et al., 2001). With the use of this procedure, it was possible to obtain Pearson correlation values between species and axes, which were converted into correlation classes: strong correlation $( \pm) 0.85 \vdash( \pm) 1$, moderate correlation $( \pm) 0.75 \vdash( \pm) 0.85$, weak correlation $( \pm) 0.60 \vdash( \pm) 0.75$, and no correlation $(< \pm 0.6)$. 
The species were grouped using a proposal of mixed guilds alpha (a) and beta $(\beta)$ similar to that described by Almeida et al. (2003). In this system, based on Telino-Júnior et al. (2005), a corresponds to the predominant diet: insectivorous $(\mathrm{I})$, omnivorous $(\mathrm{O})$, frugivorous $(\mathrm{F})$, granivorous $(\mathrm{G})$, nectarivorous $(\mathrm{N})$, and carnivorous (C). In turn, $\beta$ means preferred habitat, as follows: open areas (OA: agricultural areas, abandoned fields, and pasture), forests (FO: birds that occur in secondary forests, understory, and emergent canopy), and edges (ED: species common to the forest margin and insensitive to the edge effect and tolerant of the partial destruction of the forest habitat (Ries \& Sisk, 2010; Scherer-Neto \& Toledo, 2012). This guild proposal allows greater precision for group separation, making comparisons more robust. The proportions of individuals in each guild were compared between treatments and artificial groups using the chi-square $\left(X^{2}\right)$ test with the null hypothesis of equality - $a=$ 0.05 as the minimum limit of statistical acceptance, using, when necessary, the Yates correction (Preacher, 2001).

The ordination was carried out by means of detrended correspondence analysis (DCA), using the total abundance of individuals in each guild as variables and the sampling repetitions for each treatment as categories. Thus, it was possible to obtain Pearson correlations between guilds and axes. This test was performed to verify the possibility of guilds with a greater relationship to a given treatment or group. This analysis was performed using Pc-OrdTM ver. 6 (McCune \& Mefford, 2011). The scores of the axes between treatments and groups were tested using one-way analysis of variance (ANOVA) and the post hoc Tukey test (Quinn \& Keough, 2002).

To evaluate which groups or treatments were most similar to the bird assemblage in the source area, the similarity percentages - SIMPER (Clarke, 1993) were analyzed between treatments and groups was used, based on the annual total of records for each plot. Percentages of the species that contributed most to the dissimilarity between treatments and groups, and also to the total dissimilarity were obtained. Based on the data matrix, the ANOSIM test was used, which compared the groupings formed by the cluster analysis
(Bray-Curtis dissimilarity), with application of the Mann-Whitney post hoc test of pair-wise comparisons (Clarke, 1993). Both tests were carried out using the program Past ${ }^{\circledR}$ ver. 2.17 with 10,000 permutations (Hammer et al., 2001).

\section{Results}

In total, 4,139 contacts of 88 species distributed in 31 families were obtained. The most representative family was Thraupidae $(\mathrm{n}=$ $15 ; 17.05 \%)$, followed by Tyrannidae $(n=13$; $14.77 \%)$. Twenty-four-percent of the total records were obtained in FF and $38.22 \%$ in NC. Regarding $A P, 451$ contacts were observed for 15 families. The highest accumulated richness was found with the FF treatment $(60 \pm 2.88$ SD species), followed by NC (42 \pm 3.00 SD). The collector's curve demonstrated a pattern very close to that found between NC-AP and PR (Fig. 4a). Estimates of richness (Jackknife 1 and Chao 2) were very close to the observations, showing that the sampling was satisfactory (Fig. 4b). The highest richness means per sampling were obtained in NC $(6.83 \pm 0.27 \mathrm{SD})$ and FF (6.68 $\pm 0.27 \mathrm{SD})$, with variation between artificial groups and treatments (Fig. 4c).

The initial hypothesis was supported, because the Tukey test demonstrated that NC-AP did not diverge from PR, inferring that perches are structural factors that influence the richness in the nucleation. Moreover, in relation to richness, there was no divergence between HD and AP. A differentiated pattern was observed for the abundance in NC, which presented a higher mean number of individuals per sample (16.47 $\pm 0.59 \mathrm{SD}$ ind. $F_{[5.567]}=36.38 ; P=0.00$ ). No variation in abundance was observed between FF, NC-AP, and PR; however, these treatments were distinct from HD and AP based on the results of the Tukey's test (Fig. 4d). The same pattern observed for richness was found for diversity (Fig. 4e). Descriptive analysis using Pielou uniformity $\left(\mathrm{J}^{\prime}\right)$ confirms that FF presented the highest mean $\left(\mathrm{J}^{\prime}=0.94 \pm 0.27\right.$ SD $J^{\prime}$ units), followed by the smallest coefficient of variation ( $\mathrm{CV}=2.08 \%)$, contrary to that observed for AP $(0.57 \pm 0.27 \mathrm{SD} ; \mathrm{CV}=52.04 \%)$. More details are provided in Fig. 4 f. 

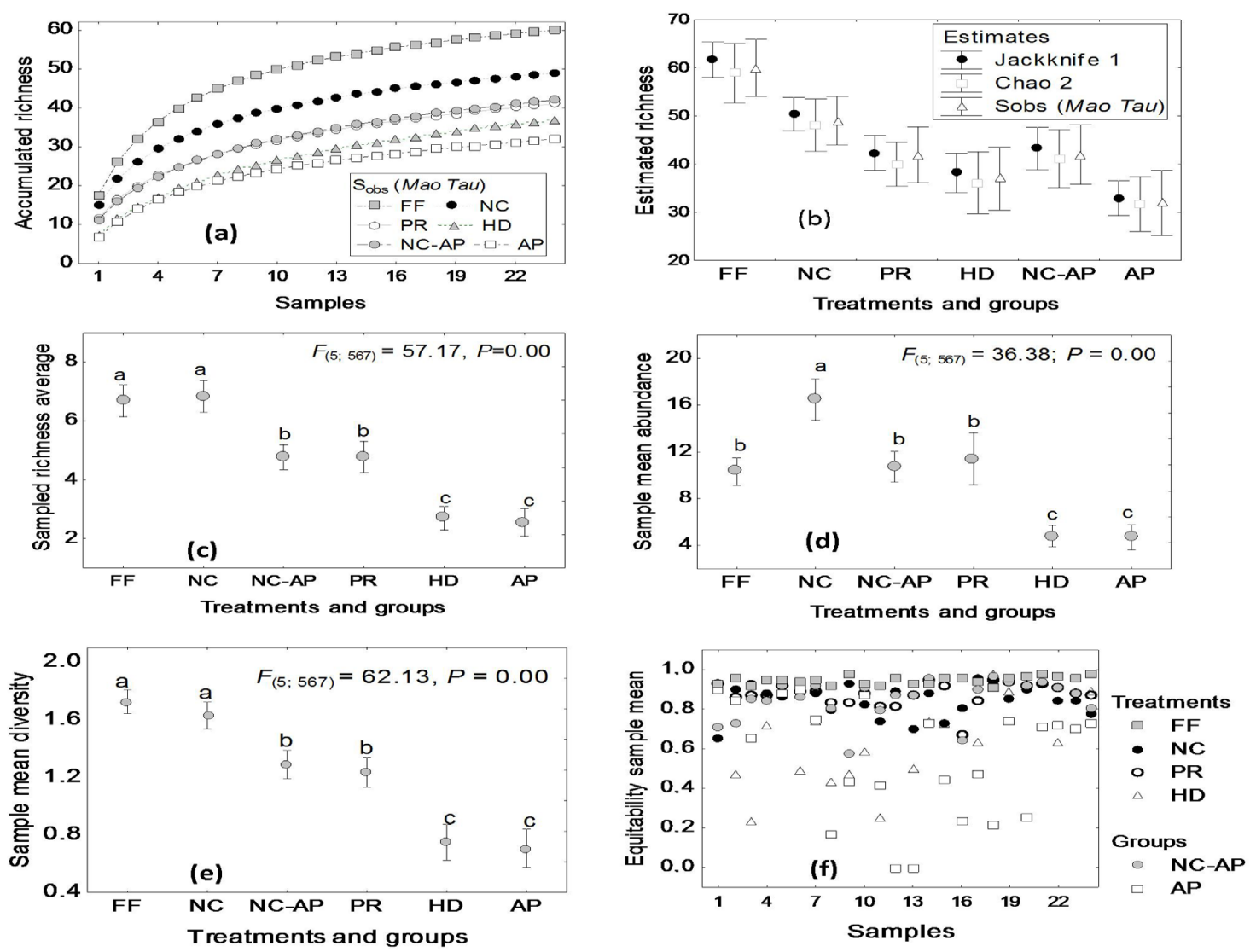

Fig. 4. Graphic representation of various parameters over seasons and samplings, as follows: (a) collector's curve for observed richness; (b) accumulated richness (Mao Tau) and estimated richness (Jackknife 1 and Chao 2), followed by the respective confidence intervals (95\%). Figure (c) demonstrates richness means between treatments and groups for each sampling; abundance (d) and diversity (e). Confidence interval $=95 \%$, means followed by the same letter do not differ based on the Tukey test $(0.05 \%)$. Annual variation in Pielou uniformity $\left(\mathrm{J}^{\prime}\right)$ for treatments and groups (f) is also shown.

The PCA demonstrated that the general pattern of abundance and richness for NC differs from that of PR (Fig. 5a). However, when records from the artificial perches (NC-AP) are discarded, this segregation does not exist. Thus, perches are sufficient to distinguish between the bird assemblage occurring in NC and PR, because they segregate for both PC 1 and PC 2 in relation to the artificial group NC-AP and other treatments (Fig. 5a-b). The first two axes of the PCA retained $60.05 \%$ of the total variance (Tab. 1).

In general, the variables (species) were weakly or uncorrelated with the axes (Tab. 1). Tyrannus melancholicus ( $r=0.89)$, Molothrus bonariensis $(r=0.80)$, Spinus magellanicus $(r$ $=0.71)$, Furnarius rufus $(r=0.70)$, Zenaida auriculata $(r=0.69)$, Columbina talpacoti $(r=$ $0.67)$, Tyrannus savana $(r=0.64)$, and Sicalis flaveola $(r=0.60)$ were essential species in the segregation of AP regarding NC, and were positively correlated with PC 2 . Specialized frugivores were absent from the perches, probably due to the defaunation recorded in the source area (FF), reflected in the experimental plots, because the only forest frugivorous species observed in FF, Chiroxiphia caudata and Pteroglossus castanotis, were not recorded in plots or on perches. 
(a)

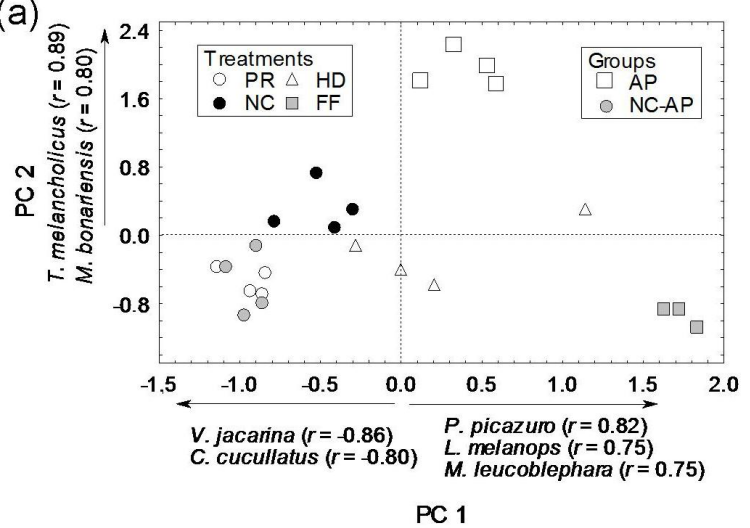

(b)

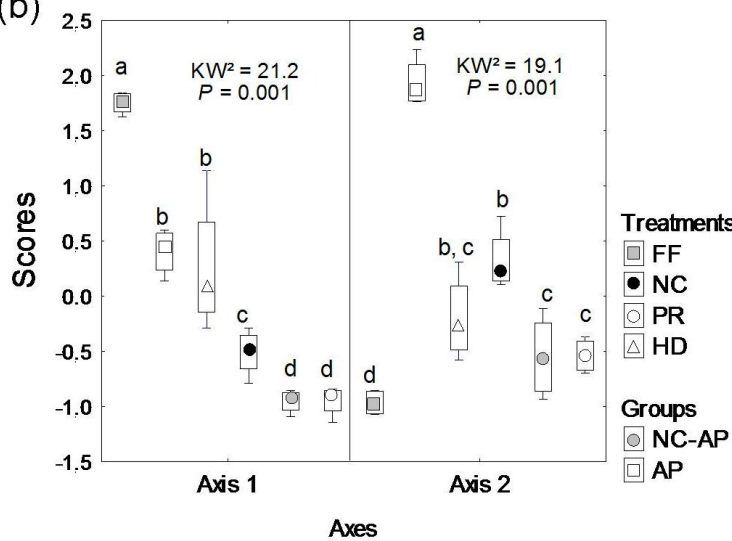

(c)

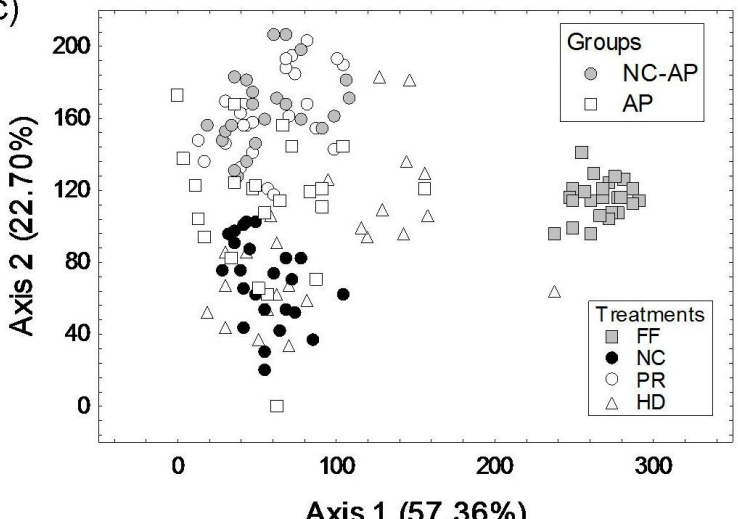

(d)

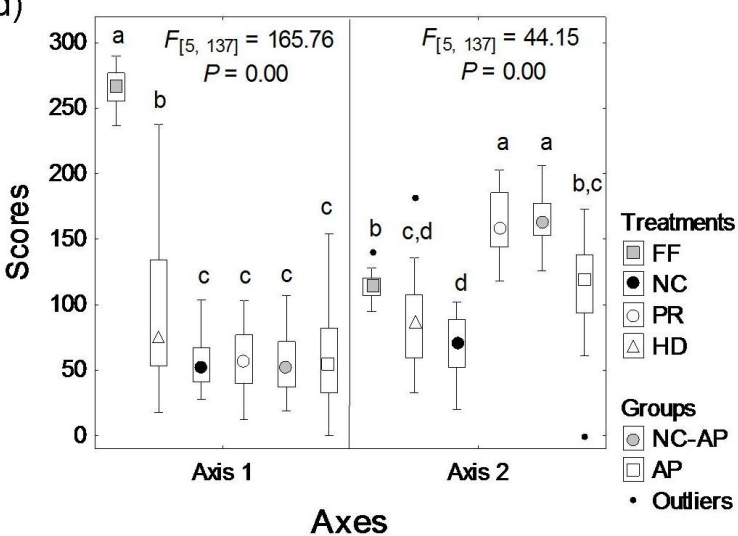

Fig. 5. Principal components analysis (a) between treatments (FF, NC, PR, and HD) and artificial groups (NC-AP and $\mathrm{AP}$ ). It was tested of the axes using Kruskal-Wallis $\left(\mathrm{KW}^{2}\right)$ non-parametric analysis of variance (b). Means followed by the same letter do not differ based on the Mann-Whitney post hoc test of pair-wise comparisons. Also shown are ordination of bird guilds by Detrended Correspondence Analysis (DCA) for experimental treatments and artificial groups (c) and (d) test of the axes using Analysis of Variance (ANOVA). Means followed by the same letter do not differ based on the post hoc Tukey's test.

Tab. 1. Variances, eigenvalues and, classes of Pearson correlations obtained by means of principal components analysis (PCA).

\begin{tabular}{lllll}
\hline Axes & Axis 1 & Axis 2 \\
\hline Variance & $41.79 \%$ & & $18.25 \%$ \\
\hline Eigenvalues & 0.02 & & 0.01 & \\
\hline Classes of correlation & $(+)$ & $(-)$ & $(+)$ & $(-)$ \\
Null & 42 & 24 & 13 & 66 \\
Weak & 15 & 2 & 7 & 0 \\
Moderate & 3 & 1 & 1 & 0 \\
Strong & 0 & 1 & 1 & 0 \\
\hline
\end{tabular}


Regarding the composition of mixed guilds, a high incidence of insectivores at the edges (IED and GED) and granivores in open areas (GOA) was found for each treatment (Tab. 2). It was only possible to verify variation in the proportions between treatments and artificial groups $\left(X^{2}=\right.$ 50,$85 ; \mathrm{df}=5 ; \mathrm{P}=0.00$ ) for the trophic grouping of insectivores in forests, with $16(27 \%)$ species in FF. Species from this guild did not occur in NC-AP. The test was not sensitive enough to detect variation between forest omnivores $\left(X^{2}=7.67\right.$; $\mathrm{df}=5 ; \mathrm{P}=0.17)$. However, the guild presented twice the number of species observed in relation to the second group, which exhibited a higher abundance.

Tab. 1. Bird guilds occurring in the experimental treatments and artificial groups. (cy) indicates that the Yates correction was used in the chi-square $\left(\chi^{2}\right)$ test. $\mathrm{OAC}=$ open area carnivores; FEF = forest edge frugivores; FOF $=$ forest frugivores; $\mathrm{OAG}=$ open area granivores; $\mathrm{FEG}=$ forest edge granivores; $\mathrm{FOG}=$ forest granivores; $\mathrm{FEI}=$ forest edge insectivores; $\mathrm{OAI}=$ open area insectivores; $\mathrm{FOI}=$ forest insectivores; $\mathrm{FEN}$ = forest edge nectarivores; $\mathrm{OAN}=$ open area nectarivores; $\mathrm{FEO}=$ forest edge omnivores; $\mathrm{OAO}=$ open area omnivores; $\mathrm{FOO}=$ forest omnivores.

\begin{tabular}{|c|c|c|c|c|c|c|c|c|}
\hline \multirow{2}{*}{ Guilds } & \multicolumn{4}{|c|}{ Treatments } & \multicolumn{2}{|c|}{ Groups } & \multicolumn{2}{|l|}{ Test } \\
\hline & $\mathrm{FF}$ & NC & PR & $\mathrm{HD}$ & NC-AP & AP & $x^{2}$ & $P$ \\
\hline OAC & 2 & 3 & 1 & 1 & 2 & 2 & $0.545 c y$ & 0.99 \\
\hline FEF & 1 & 1 & 0 & 0 & 0 & 0 & $0.50 \mathrm{cy}$ & 1.99 \\
\hline FOF & 2 & 0 & 0 & 0 & 0 & 0 & $4.50 \mathrm{cy}$ & 0.48 \\
\hline FOG & 2 & 1 & 1 & 1 & 1 & 0 & $1.50 \mathrm{cy}$ & 0.91 \\
\hline FEG & 3 & 2 & 1 & 1 & 2 & 1 & $0.50 \mathrm{cy}$ & 0.99 \\
\hline OAG & 4 & 12 & 11 & 9 & 12 & 10 & 3.00 & 0.70 \\
\hline FEI & 6 & 5 & 5 & 5 & 4 & 2 & 2.11 & 0.83 \\
\hline FOI & 16 & 1 & 1 & 1 & 0 & 1 & $50.85 \mathrm{cy}$ & 0.00 \\
\hline OAI & 4 & 12 & 12 & 8 & 11 & 7 & 5.78 & 0.33 \\
\hline FEN & 1 & 0 & 1 & 0 & 0 & 0 & $0.50 \mathrm{cy}$ & 0.99 \\
\hline OAN & 1 & 1 & 1 & 1 & 1 & 1 & 1.50 & 0.91 \\
\hline FEO & 3 & 2 & 0 & 1 & 1 & 2 & $1.33 \mathrm{cy}$ & 0.93 \\
\hline OAO & 1 & 2 & 1 & 2 & 1 & 2 & $0.00 \mathrm{cy}$ & 1.00 \\
\hline FOO & 14 & 7 & 6 & 7 & 7 & 4 & 7.67 & 0.17 \\
\hline Total & 14 & 12 & 11 & 11 & 10 & 10 & 0.54 & 0.97 \\
\hline
\end{tabular}

Ordination of guild abundance (Fig. 5c) allows FF segregation on axis 1 to be verified in relation to the other treatments and groups. The analysis was mainly influenced by forest insectivores $(r=0.83)$, forest omnivores $(r=0.78)$, and forest granivores $(r=0.78)$. There was segrega- tion (only on axis 2) between NC and NC-AP (Fig. $5 c-d)$, where forest edge granivores $(r=0.68)$ positively influenced NC-AP, while open-area insectivores negatively influenced NC on axis 2, which segregated from NC-AP and PR $(r=-0.58)$. Details are provided in Tab. 3 and Fig. 5. 
Tab. 3. Correlation values between the abundance in guilds (variables) and axes of the detrended correspondence analysis $(\mathrm{DCA}) . \mathrm{OAC}=$ open area carnivores; $\mathrm{FEF}=$ forest edge frugivores; $\mathrm{FOF}=$ forest frugivores; $\mathrm{OAG}=$ open area granivores; FEG $=$ forest edge granivores; FOG $=$ forest granivores; $\mathrm{FEI}=$ forest edge insectivores; $\mathrm{OAI}=$ open area insectivores; $\mathrm{FOI}=$ forest insectivores; $\mathrm{FEN}=$ forest edge nectarivores; $\mathrm{OAN}=$ open area nectarivores; $\mathrm{FEO}=$ forest edge omnivores; $\mathrm{OAO}=$ open area omnivores; $\mathrm{FOO}=$ forest omnivores.

\begin{tabular}{lll}
\hline Guilds & Axis $\mathbf{1}(\mathbf{r})$ & Axis $\mathbf{2}(\mathbf{r})$ \\
\hline OAC & -0.126 & -0.394 \\
FEF & 0.232 & 0 \\
FOF & 0.247 & -0.035 \\
FOG & 0.782 & 0.061 \\
FEG & -0.097 & 0.686 \\
OAG & -0.552 & 0.202 \\
FEI & -0.214 & -0.375 \\
FOI & 0.833 & -0.114 \\
OAI & -0.455 & -0.581 \\
FEN & 0.45 & -0.018 \\
OAN & -0.135 & 0.159 \\
FEO & 0.43 & -0.087 \\
FOO & 0.786 & 0.005 \\
OAO & 0.134 & -0.072 \\
\hline Eigenvalues & $\mathbf{0 . 5 7}$ & $\mathbf{0 . 2 2}$ \\
\hline
\end{tabular}

Using the SIMPER test (Tab. 4), the assemblages between treatments and groups were not found to be similar to the source fragment. The highest dissimilarity was between FF and AP (93.7) and the lowest between FF and HD (84.1). Turdus leucomelas contributed most to the dissimilarity between FF and HD (8.51\% of the variation). Between AP and NC-AP, the abundance of Sporophila caerulescens provided $15.63 \%$ of the dissimilarity. This species had the greatest influence on the dissimilarity between NC and PR
(16.23\%). The dissimilarity between NC-AP and PR was related to the abundance of Volatinia jacarina $(19.82 \%)$.

Simultaneous comparison of the groups (SIMPER) revealed a total dissimilarity of $69.07 \%$. This was mainly influenced by the abundance of V. jacarina $(13.33 \%)$, which was not recorded in FF. According to the multivariate analysis of similarity (ANOSIM), FF and HD formed distinct groups, while NC, PR, and NC-AP formed a group.

Tab. 4. Bray-Curtis dissimilarity in relation to the similarity of percentages (SIMPER). Probability values for pairwise comparisons of the multivariate analysis of similarity (ANOSIM) are in italics. Values with $\left({ }^{*}\right)$ represent significant probabilities $(\mathrm{P}<0.05)$, demonstrating differences between treatments or groups.

\begin{tabular}{c|cccc|cc}
\hline \multicolumn{1}{c}{} & FF & NC & PR & \multicolumn{1}{c}{ HD } & \multicolumn{1}{c}{ NC-AP } & AP \\
\cline { 2 - 7 } FF & - & 91.33 & 93.20 & 84.10 & 92.50 & 93.70 \\
NC & $0.028^{*}$ & - & 38.98 & 66.47 & 35.73 & 63.09 \\
$\mathbf{P R}$ & $0.029 *$ & 0.060 & - & 62.04 & 32.96 & 69.07 \\
HD & $0.028 *$ & $0.030 *$ & $0.030 *$ & - & 60.72 & 64.91 \\
\cline { 2 - 5 } NC-AP & $0.027 *$ & $0.029 *$ & 1 & $0.027 *$ & - & 69.69 \\
AP & $0.031^{*}$ & 0.145 & $0.030 *$ & $0.030^{*}$ & $0.030 *$ & - \\
\hline
\end{tabular}




\section{DIscussion}

The species total $(n=88)$ represents approximately $48 \%$ of that observed in fragments of seasonal semideciduous forest in northern Paraná state (Bornschein \& Reinert, 2000) and 73\% of that reported by Bispo \& Scherer-Neto (2010) in a fragment of a mixed ombrophilous forest in the eastern part of the state. Both studies were performed in forest fragments surrounded by an agricultural matrix. Thus, as this was an ecotone between a seasonal and ombrophilous forest, only a fraction of the species total with occurrence potential were recorded.

Richness estimators (Jackknife 1 and Chao 2) demonstrated sufficient sampling of the local avifauna. Total richness was similar to that observed by Pillatt et al. (2010) with 87 species in seasonal forest remainders and agricultural areas in southern Brazil, although species composition differences were noted. The structural characteristics of the avifauna occurring in this study demonstrated a pattern that is expected for altered areas, lacking species that are highly susceptibile to disturbances (Anjos, 2004, 2006) and bioindicator families, such as Dendrocolaptidae (Poletto et al., 2004).

Richness was lower with every treatment and group compared with the forest fragment. According to Fuller et al. (2001) and Herzon et al. (2014), recently restored environments do not fully support forest species, but can function as complementary habitats, alleviating the pressure of competition between some species and increasing regional diversity through the creation of a land-use mosaic. This pattern is consistent with the findings of Lindell et al. (2012), whereby recently restored environments were capable of furnishing environmental value to many bird species.

The analysis of variance for richness, abundance, and diversity (Fig. 4a-c) indicates that applied nucleation is similar to passive restoration when records obtained from the artificial perches are discarded. Therefore, the initial hypothesis was supported. The artificial perches provided an additional niche and, in this study, represented $34 \%$ of the increase in the accumulated richness observed in NC. According to some researchers, this role of the perches partially substitutes the bird-attracting function of isolated trees in agricultural landscapes, producing more environmental complexity (Bocchese et al., 2008; Sheldon \& Nadkarni, 2013).

Evenness variation was the highest in FF. This infers that dominance is lower in FF and suggests a stability gradient (FF > NC > PR > HD), corroborating the findings of Reis et al. (2007), who stated that "nucleating actions are complemented in the sense of rapidly forming a more stabilized community."

It is interesting to note that during 2 years of restoration, AP provided an ecosystem value as important as that of HD, because the metric parameters that compose the diversity were similar, with no statistical differences based on the tests used. According to Ortega-Álvarez et al. (2013), removal of the understory vegetation limits the number of species in restored environments. This limitation occurs due to the reduced foraging strata (Lindenmayer et al., 2010). Thus, management in high-diversity planting, with the removal of emergent herbaceous vegetation, reduces the number of available niches and, therefore, limits the number of species (Vickery et al., 2002).

The Thraupidae family with the greatest species richness is directly related to the recent inclusion of the family Emberizidae (Piacentini et al., 2015). However, similarity in terms of accumulated richness between AP and HD is probably related to the abundance and richness of the family Tyrannidae. According to Gabriel \& Pizo (2005); Silva et al. (2010), and Martins-Oliveira et al. (2012), flycatchers use both dry perches and plant canopies to forage for insects. Thus, AP and HD furnish this group a similar niche, because young trees provide natural perches during the two years of growth. Flycatchers are frequently observed carrying out frugivory in both forest habitats and in altered environments, making them insectivores or generalist omnivores with the ability to consume fruits and disperse intact seeds (Pizo, 2004, 2007; Athiê \& Dias, 2012).

The attention given to species that perform frugivory and dispersal in ecological restoration studies limits our understanding of perch use patterns of granivorous birds, as well as their importance. In this study, open-area granivores and forest edge granivores represented $34.37 \%$ of the total species in AP. The highest abundance per sample was recorded in NC; however, the exclusion of records obtained from the artificial perches showed a similar pattern between NC-AP and PR. Thus, the abundance observed on the perches is believed to be influenced by gregarious species (e.g., S. magellanicus and M. bonariensis), as the PCA suggests. This overestimates the abundance of the sample (Ortega-Álvarez et al., 2013).

Perches are used in different ways by granivorous birds (Shiels \& Walker, 2003; Bocchese et al., 2008). S. caerulescens contributed $15.63 \%$ of the dissimilarity between AP and NC-AP, showing that artificial perches can function as places to rest or socialize, because although frequently used by S. caerulescens, they do not offer direct food resources to this species. The occurrence of $M$. bonariensis weighed heavily in the separation between NC and NC-AP (Fig. 5a), conferring a negative effect, because the species presents brood parasitism and uses perches to monitor the construction of host nests (Banks \& Martin, 2001).

The main difference in the bird assemblage between FF and the other treatments and groups was due to the presence of forest insectivores, omnivores, and granivores. However, few studies 
have investigated the role of exclusively forest insectivores in dispersal and forest restoration. Some of the insectivores recorded in this study, e.g., Setophaga pitiayumi, Colaptes melanochloros, and Myiodynastes maculatus are frequently recorded consuming fruits (Jesus \& Monteiro-FiIho, 2007; Kaminski, 2013).

Forest insectivores are naturally limited to colonizing agricultural environments and open areas due to their low mobility and specific environmental requirements (Sekercioglu, 2012). Thus, alternatives should be identified to favor colonization by this guild. According to Sheldon \& Nadkarni (2013), the presence of lianas and epiphytes is crucial to attract forest insectivores in open environments. Thus, isolated trees covered by lianas are more attractive than perches for this group.

Among the forest omnivores, $T$. leucomelas was responsible for most of the dissimilarity between FF and HD. Thrushes are characterized as frugivorous omnivores with a great capacity to disperse (with quality) forest seeds (Mota-Gomes et al., 2008; Gasperin \& Pizo, 2012). A similar result was obtained by Wal et al. (2012), whereby another thrush, Turdus grayi, contributed the most to dissimilarity between planted forests and agrosystems. This group of omnivores can carry out reasonable movements in the landscape (Cardoso-da-Silva et al., 1996). Thus, they are the most suitable candidates for the use of artificial perches, such as ecological trampolines as highlighted by Reis et al. (2007, 2010), allowing the dissemination of seeds between fragments.

The similarity between FF and HD was the highest, indicating that during the first 2 years, high-diversity planting possesses a greater capacity to attract forest species. This pattern was confirmed by SIMPER analysis, indicating lower dissimilarity between the forest fragment and high-diversity planting. Thus, the use of rapid-growth pioneer species in HD probably brings about a shaded environment, which reduces the proliferation of grasses (Carvalho et al., 1995). In this way, the number of open-area granivores will decrease (Vickery et al., 2002; Fuller, 2012). The planting of slow-growing species helps to form a precocious stratification between pioneer and non-pioneer species in HD. This should favor insectivores over the long term, because of the increase in different leaf strata (Willson, 1974; Marzluff \& Ewing, 2001).

If with the succession, the tendency of attractiveness for forest species were maintained in $\mathrm{HD}$, high-diversity planting would probably reach (in less time) characteristics of an environment in the late primary stage of ecological succession, leading to a more adequate environment for the maintenance of bird species dependent on the forest, and, thus, supporting conservation efforts (Lindell et al., 2012; Reid et al., 2012).

The low similarity between experimental treatments, in relation to the source fragment suggests that colonization during the first 2 years is by mobile species that occur at the edges of adjacent plantations and farms, emphasizing the importance of these sites as sources of colonizer species (Vickery et al., 2002; Sekercioglu, 2012). According to Haslem \& Bennett (2008) and Herzon et al. (2014), the capacity to colonize new environments is related to species abundance in the source areas. In the present study, each species was recorded once, indicating that FF is also restrictive in the maintenance of specialized frugivores, limiting colonization processes in other areas.

\section{ACKNOWLEDgMENTS}

We thank Conselho de Desenvolvimento Científico Tecnológico (CNPq) for financing the project (process no. 575081/2008-2) and Companhia Paranaense de Energia (COPEL), especially Murilo Barddal, for providing logistic support and for implantation and forest maintenance. We also thank the forest technician Gilmar Poser Brizola for help in the field. We are grateful to the Programa em Ecologia de Ambientes Aquáticos Continentais (PEA) and the Universidade Tecnológica Federal do Paraná. HFV thanks CAPES (Coordenação de Aperfeiçoamento de Pessoal de Nível Superior) for the scholarship.

\section{REFERENCES}

Akçakaya, H. R., G. Mills \& C.P. Doncaster. 2007. The role of metapopulations in conservation, p.64-84. In D.W. Macdonald \& K. Service (ed.). Key Topics in Conservation Biology. Oxford, Blackwell Scientific Publications.

Almeida, A.; H. T. Z. Couto \& A. F. Almeida. 2003. Diversidade beta de aves em habitats secundários da Pré-Amazônia maranhense e interação com modelos nulos. Ararajuba 11(1): 157-171.

Anderson, M. L. 1953. Spaced-Group planting. Unasylva 7(2):1-15.

Anjos, L. 2004. Species richness and relative abundance of birds in natural and anthropogenic fragments of Brazilian Atlantic forest. Anais da Academia Brasileira de Ciências 76(2):429434. http://dx.doi.org/10.1590/S000137652004000200036

Anjos, L. 2006. Bird Species Sensitivity in a Fragmented Landscape of the Atlantic Forest in Southern Brazil1. Biotropica 38(2):229234. http://dx.doi.org/10.1111/j.17447429.2006.00122.x 
Anjos, L. 2007. A eficiência do método de amostragem por pontos de escuta na avaliação da riqueza de aves. Revista Brasileira de Ornitologia 15(2): 239-243.

Athiê, S. \& M. M. Dias. 2012. Frugivoria por aves em um mosaico de Floresta Estacional Semidecidual e refl orestamento misto em Rio Claro, São Paulo, Brasil. Acta Botanica Brasilica 26(1): 84-93. http://dx.doi. org/10.1590/S0102-33062012000100010

Báldi, A. \& P. Batári. 2011. Spatial heterogeneity and farmland birds: different perspectives in Western and Eastern Europe. Ibis 153: 875-876. http://dx.doi.org/10.1111/ j.1474-919X.2011.01169.x

Banks, A. J. \& T. E. Martin. 2001. Host activity and the risk of nest parasitism by brown-headed cowbirds. Behavioral Ecology 12(1): 31-40.

Bechara, F. C., S. J. Dickens, E. C. Farrer, L. Larios, E. N. Spotswood, P. Mariotte \& K. N. Suding 2016. Neotropical rainforest restoration: comparing passive, plantation and nucleation approaches. Biodiversity and Conservation 25: 2021-2034.

Beltrame, T. P. \& E. Rodrigues. 2008. Comparação de diferentes densidades de feijão guandu (Cajanus cajan (L.) Millsp.) na restauração florestal de uma área de reserva legal no Pontal do Paranapanema, SP. Scientia Forestalis 36(80): 317-327.

Bibby, C.J., N. D. Burgess, D. A. Hill \& S. H. Mustoe. 2000. Bird Census Techniques. 2nd ed. Academic Press, London

Bispo, A. A. \& P. Scherer-Neto. 2010. Avian assemblage in a remnant of the Araucaria Forest in the Southeast Parana, Brazil. Biota Neotrópica 10(1):121-130. http://dx.doi. org/10.1590/S1676-06032010000100012

Bocchese, R. A., A. K. M., Oliveira, S. Favero, S. J. S. Garnés \& V. A. Laura. 2008. Chuva de sementes e estabelecimento de plântulas a partir da utilização de árvores isoladas e poleiros artificiais por aves dispersoras de sementes, em área de Cerrado, Mato Grosso do Sul, Brasil. Revista Brasileira de Ornitologia 16(3):207-213.

Bornschein, M. R. \& B. L. Reinert. 2000. Aves em três remanescentes florestais no norte do estado do Paraná, sul do Brasil, com sugestões para conservação e manejo. Revista Brasileira de Zoologia 17(3):615-633. http://dx.doi.org/10.1590/S010181752000000300008
Brady, C. J. \& R. A. Noske. 2010. Succession in Bird and Plant Communities over a 24-Year Chronosequence of Mine Rehabilitation in the Australian Monsoon Tropics. Restoration Ecology 18(6): 855-864. http://dx.doi.org/10.1111/j.1526100X.2008.00511.x

Cardoso-da-Silva, J. M., C. Uhl \& G. Murray. 1996. Plant succession, Landscape Manegement, and the Ecology of Frugivorous Birds in Abandoned Amazonian Pastures. Conservation Biology 10(2): 491-505. http://dx.doi.org/10.1046/ j.1523-1739.1996.10020491.x

Carvalho, M. M., V. P. Freitas \& A. C. Andrade. 1995. Crescimento inicial de cinco gramíneas tropicais em um sub-bosque de angico vermelho (Anadenanthera macrocarpa Benth.). Pasturas Tropicales 17(1): 24-30.

Clarke, K. R. 1993. Non-parametric multivariate analyses of changes in community structure. Austral Ecology 18(1): 117-143. http:// dx.doi.org/10.1111/j.1442-9993.1993. tb00438. $x$

Colwell, R. K. 2011. EstimateS, Version 8.2: Statistical Estimation of Species Richness and Shared Species from Samples. http:// viceroy.eeb.uconn.edu/estimates

Colwell, R. K., C. X. Mao \& J. Chang. 2004. Interpolating, extrapolating, and comparing incidence-based species accumulation curves. Ecology 85(10): 2717-2727. http:// dx.doi.org/10.1890/03-0557

Corbin, J. D. \& K. D. Holl. 2012. Applied nucleation as a forest restoration strategy. Forest Ecology and Management 265(1): 37-46. http://dx.doi.org/10.1016/j.foreco.2011.10.013

Corder G. W. \& D. I. Foreman. 2009. Nonparametric statistics for non-statisticians: a step-by-step approach. Wiley, New Jersey.

Esler, D. 2000. Applying Metapopulation Theory to Conservation of Migratory Birds. Conservation Biology 14(2):366-372.

Fink, R. D., C.A. LIndell, E.B.R. Morrison, A. Zahawi \& K.D. Holl. 2009. Patch Size and Tree Species Influence the Number and Duration of Bird Visits in Forest Restoration Plots in Southern Costa Rica. Restoration Ecology 17(4):479-486. http://dx.doi. org/10.1111/j.1526-100X.2008.00383.x 
Fuller, R.J. 2012. The bird and its habitat: an overview of concepts. Cambridge University Press, Cambridge.

Fuller, R. J., D. E. Chamberlain, N. H. K Burton \& S. J. Gough. 2001. Distributions of birds in lowland agricultural landscapes of England and Wales: How distinctive are bird communities of hedgerows and woodland? Agriculture, Ecosystems and Environment 84(1): 79-92.

Gabriel, V. A. \& M. A. Pizo. 2005. Foraging behavior of tyrant flycatchers (Aves, Tyrannidae) in Brazil. Revista Brasileira de Zoologia 22(4): 1072-1077. http://dx.doi. org/10.1590/S0101-81752005000400036

Gandolfi, S., S. V. Martins \& R. R. Rodrigues. 2007. Forest Restoration: Many Views and Objectives. High Diversity Forest Restoration in Degraded Areas, Nova Science Publishers INC, New York

Gasperin, G. \& M. A. Pizo. 2012. Passage time of seeds through the guts of frugivorous birds, a first assessment in Brazil. Revista Brasileira de Ornitologia 20(1): 48-51.

Gerber, D., T. Y. Kiwara, P. R. Souza, M. Lubke, E. S. Vismara \& F. C. Bechara. Canopy and invasive grasses cover effects in distinct ecological restoration technologies: 5-y monitoring in a Brazilian subtropical forest. Acta Biológica Catarinense, v. 4, p. 54-59, 2017.

Golawski, A. \& S. Golawska. 2013. Are the birds dangerous for insect pollinators? The relationship between hymenopterans and the red-backed shrike. Journal of Insect Conservation 17: 1155-1160. http://dx.doi. org/10.1007/s10841-013-9596-2

Gonçalves, R. M. G., E. Giannotti, J. D. G. Giannotti \& A. A. Silva. 2005. Aplicação de modelo de Revegetação em áreas degradadas, visando à restauração ecológica da Microbacia do córrego da Fazenda Itaqui, no município de Santa Gertrudes, SP. Revista do Instituto Florestal 17(1): 73-95.

Gorenstein M. R., F. C. Bechara, D. A. Estevan, A. S. Sgarbi \& I. C. Gallo. 2011. Estrutura e diversidade da comunidade arbórea na trilha ecológica da UTFPR, Campus Dois Vizinhos através do método de Quadrantes. In V Seminário: Sistemas de Produção Agropecuária - Ciências Agrárias, Animais e Florestais - UTFPR. Dois Vizinhos, 2011. Anais... 1: 01-05.
Graham, L. L. B. \& S. E. Page. 2012. Artificial Bird Perches for the Regeneration of Degraded Tropical Peat Swamp Forest: A Restoration Tool with Limited Potential. Restoration Ecology 20(5): 631-637. http://dx.doi. org/10.1111/j.1526-100X.2011.00805.x

Guedes, M. C., V. A. Melo \& J. J. Griffith. 1997. Uso de poleiros artificiais e ilhas de vegetação por aves dispersoras de sementes. Ararajuba 52(2): 229-232.

Hall, T. R., W. E. Howard \& R. E. Marsh. 1981. Raptor Use of Artificial Perches. Wildlife Society Bulletin 9: 296-298.

Hammer, Ø., D. A. T. Harper \& P. D. Ryan. 2001. Paleontological statistics software package for education and data analysis. Palaeontologia Electronica 4(1): 01-09.

Haslem, A. \& A.F. Bennett. 2008. Countryside elements and the conservation of birds in agricultural environments. Agriculture, Ecosystems \& Environment 125(14):191-203. http://dx.doi.org/10.1016/j. agee.2008.01.001

Herzon, I., R. Marja, S. Menshikova \& A. Kondratyev. 2014. Farmland bird communities in an agricultural landscape in Northwest Russia: Seasonal and spatial patterns. Agriculture, Ecosystems and Environment 183: 78-85 http://dx.doi.org/10.1016/j. agee.2013.10.015

Holl, K. D. 1998. Do Bird Perching Structures Elevate Seed Rain and Seedling Establishment in Abandoned Tropical Pasture? Restoration Ecology 6(3): 253-261. http://dx.doi.org/10.1046/j.1526100X.1998.00638.X

Holl, K. D., M. E. Loik, E. H. V. Lin \& I. A. Samuels. 2000. Tropical Montane Forest restoration in Costa Rica: Overcoming Barriers to Dispersal and Establishment. Restoration Ecology 8(4): 339-349. http://dx.doi. org/10.1046/j.1526-100x.2000.80049.x

Horgan, F. G., A. F. Ramal, J. M. Villegas, M. L. P. Almazan, C. C. Bernal, J. M. P. Jamoralin, M. L. P. Almazan, C. C. Bernal, A. Jamoralin, J. M. Pasang, G. Orboc, V. Agreda \& C. Arroyo. 2016. Ecological engineering with high diversity vegetation patches enhances bird activity and ecosystem services in Philippine rice fields. Regional Environmental Change 6: 1-13. http:// dx.doi.org/10.1007/s10113-016-0984-5 
Hurlbert, A. H. 2004. Species-energy relationships and habitat complexity in bird communities. Ecology Letters 7(8): 714-720. http://dx.doi.org/10.1111/j.14610248.2004.00630.x

Jesus, S. \& E. L. A. Monteiro-Filho, 2007. Frugivoria por aves em Schinus terebinthifolius (Anacardiaceae) e Myrsine coriacea (Myrsinaceae). Revista Brasileira de Ornitologia 15(4): 585-591.

Johnson, R. A. \& D. W. Wichern. 2007. Applied Multivariate Statistical Analysis. 6. ed. Prentice Hall, Nova York.

Jordan, W. R., M. E. Gilpin \& J. D. Aber, 2003. Restoration ecology: A synthetic approach to ecological restoration. Cambridge University Press, Cambridge.

Kaminski, N. 2013. Consumo de frutos por três espécies de Picidae em área de Floresta Ombrófla Mista de Santa Catarina. Biotemas 26(3): 261-263. http://dx.doi. org/10.5007/2175-7925.2013v26n3p261

Krebs, C. J. 1999. Ecological Methodology. Ecological Methodology. Harper and Row, New York.

Lindell, C. A., R. J Cole, K. D. Holl \& R. A. Zahawi. 2012. Migratory bird species in young tropical forest restoration sites: effects of vegetation height, planting design, and season. Bird Conservation International 22(1):94-105. http://dx.doi.org/10.1017/ S0959270911000177

Lindenmayer, D. B., E. J. Knight, M. J. Crane, R. Montague-Drake, D. R. Michael \& C. I Macgregor. 2010. What makes an effective restoration planting for woodland birds? Biological Conservation 143: 289-301.

Martins-Oliveira, L., R. Leal-Marques, C.H Nunes, A. G. Franchin \& Marçal-Júnior, 0. 2012. Forrageamento de Pitangus sulphuratus e de Tyrannus melancholicus (Aves: Tyrannidae) em habitats urbanos. Bioscience Journal 28(6):1038-1050.

Marzluff, J.M. \& K. Ewing. 2001. Fragmented Landscapes for the Conservation of Birds: A General Framework and Specific Recommendations for Urbanizing Landscapes. Restoration Ecology 9(3): 280-292. http://dx.doi.org/10.1046/ j.1526-100x.2001.009003280.x
McCune, B. \& M. J. Mefford. 2011. PC-ORD. Multivariate Analysis of Ecological Data. Oregon: MjM Software.

McDonnel, M. J. \& E. W. Stiles. 1983. The structural complexity of old field vegetation and recruitment of bird-dispersed plant species. Oecologia 56(1):109-116.

Melo, A. S. 2008. O que ganhamos "confundindo" riqueza de espécies e equabilidade em um índice de diversidade? Biota Neotropica 8(3): 21-27. http://dx.doi.org/10.1590/ S1676-06032008000300001

Mota-Gomes, V. S., M. C. R. Correia, H. A. Lima \& M. A. S. Alves. 2008. Potential role of frugivorous birds (Passeriformes) on seed dispersal of six plant species in a restinga habitat, southeastern Brazil. Revista de Biología Tropical 56 (1): 205-216.

Odum, E. P. 1950. Bird populations of the Highlands (North Carolina) Plateau in relation to plant succession and avian invasion. Ecology 31:587-605. http://dx.doi. org/10.2307/1931577

Ortega-Álvarez, R., R. Lindig-Cisneros, I. Macgregor-Fors, K. Renton \& J. E. Schondube. 2013. Avian community responses to restoration efforts in a complex volcanic landscape. Ecological Engineering 53: 275-283. http://dx.doi.org/10.1016/j. ecoleng.2012.12.058

Piacentini V. Q., A. Aleixo, C. E. Agne, G. N. Maurício, J. F. Pacheco, G. A. Bravo, G. R. R. Brito, L. N. Naka, F. Olmos, S. Posso, L. F. Silveira, G. S. Betini, E. Carrano, I. Franz, A. C. Lees, L. M. Lima, D. Pioli, F. Schunck, F. R. Amaral, G. A. Bencke, M. Cohn-Haft, L. F. A Figueiredo, F. C. Straube \& E. Cesari. 2015. Annotated checklist of the birds of Brazil by the Brazilian Ornithological Records. Revista Brasileira de Ornitologia 23(2): 91-298.

Pias, K. E., Z. C. Welch \& W. M. Kitchens. 2012. An Artificial Perch to Help Snail Kites Handle an Exotic Apple Snail. Waterbirds 35(2): 347-351. http://www.bioone.org/ doi/full/10.1675/063.035.0217

Pillatt, N., N. Pillatt, E. T. H. F. Franco \& G. C. Coelho. 2010. Dry artifcial perches and the seed rain in a subtropical riparian forest. Brazilian Journal of Biosciences 8(3):246252. 
Pizo, M. A. 2004. Frugivory and habitat use by fruit-eating birds in a fragmented landscape of southeast Brazil. Ornitologia Neotropical 15(suppl.): 117-126.

Pizo, M. A. 2007. Frugivory by birds in degraded areas of Brazil. In: A.J. Dennis, E. W. Schupp, R. J. Green \& D.W. Westcot (eds.). Seed dispersal - theory and its application in a changing world, p. 615-627. Oxford shire, UK: CAB International, Oxford.

Poletto, F., L. Anjos, E. V. Lopes, G. H. Volpato, P.P. Serafini \& F. L. Favaro. 2004. Caracterização do microhabitat e vulnerabilidade de cinco spécies de arapaçus (Aves: Dendrocolaptidae) em fragmento florestal do norte do estado do Paraná, sul do Brasil. Ararajuba 12(2): 89-96.

Preacher, K. J. 2001. Calculation for the ChiSquare test: An interactive calculation tool for chi-square tests of goodness of fit and independence. Retrieved from http:// quantpsy.org.

Quinn, G. P. \& M. J. Keough. 2002. Experimental Design and Data Analysis for Biologists. Cambridge University Press, New York

Reis, A., F. C. Bechara, M. B. Espíndola, N. K. Vieira \& L.L. Sousa. 2003. Restauração de áreas degradadas: a nucleação como base para incrementar os processos sucessionais. Natureza \& Conservação 1(1): 28-36.

Reis, A., F. C. Bechara \& D. R. Tres. 2010. Nucleation in tropical ecological restoration. Scientia Agrícola 67(2): 244-250. http://dx.doi.org/10.1590/S010390162010000200018

Reis, A., D. R. Tres \& E. C. Scariot. 2007. Restauração da Floresta Ombrófila Mista através de sucessão natural. Pesquisa Florestal Brasileira 55(2): 67-73.

Reid, J. L., J. Berton, C. Harris \& R. A. Zahawi. 2012a. Avian Habitat Preference in Tropical Forest Restorationin Southern Costa Rica. Biotropica 44(3):350-359. http://dx.doi.org/10.1111/j.17447429.2011.00814.x

Rey-Benayas, J. M., J. M. Bullock \& A. C. Newton. 2008. Creating woodland islets to reconcile ecological restoration, conservation, and agricultural land use. Frontiers in Ecology and the Environment 6(6): 329336. http://dx.doi.org/http://dx.doi. org/10.1890/070057
Ries, L. \& T. D. Sisk. 2010. What is an edge species? The implications of sensitivity to habitat edges. Oikos 119(10): 1636-1642. http://dx.doi.org/10.1111/j.16000706.2010.18414.x

Rodrigues, R. R., R. A. F. Lima, S Gandolfi \& A. G. Nave. 2009. On the restoration of high diversity forests: 30 years of experience in the Brazilian Atlantic Forest. Biological Conservation 142(6): 12421251. http://dx.doi.org/10.1016/j.biocon.2008.12.008

Rodrigues, R. R., S. Gandolfi, A. G. Nave, J. Aronson, T. E. Barreto, C. Y. Vidal \& P. H. S. Brancalion. 2011. Large-scale ecological restoration of high diversity tropical forests in SE Brazil. Forest Ecology and Management 261(10): 1605-1613. http://dx.doi. org/doi: 10.1016/j.foreco.2010.07.005

Sanderson, F. J., M. Kucharz, M. Jobda \& P. F. Donald. 2013. Impacts of agricultural intensification and abandonment on farmland birds in Poland following EU accession. Agriculture, Ecosystems \& Environment 168: 16-24. http://dx.doi.org/10.1016/j. agee.2013.01.015

Scherer-Neto, P. \& M. C. B Toledo. 2012. Bird community in an Araucaria forest fragment in relation to changes in the surrounding landscape in Southern Brazil. Iheringia. Série Zoologia 102(4): 412-422. http://dx.doi.org/10.1590/S007347212012000400007

Schieck, J. \& S. J. Song. 2006. Changes in bird communities throughout succession following fire and harvest in boreal forests of western North America: literature review and meta-analyses. Canadian Journal of Forest Research 36: 1299-1318. http:// dx.doi.org/10.1139/x06-017

Sekercioglu, C. H. 2012. Bird functional diversity and ecosystem services in tropical forests, agroforests and agricultural areas. Journal of Ornithology 153(1):153-161. http://dx.doi.org/10.1007/s10336-0120869-4

Sheldon, K. S. \& N. M. Nadkarni. 2013. The use of pasture trees by birds in a tropical montane landscape in Monteverde, Costa Rica. Journal of Tropical Ecology 29(5):459-462. http://dx.doi.org/10.1017/ S0266467413000503 
Shiels, A.B. \& L. R. Walker. 2003. Birds Perches Increase Forest Seeds on Puerto. Restoration Ecology 11: 457-465.

Shono, K., E. A. Cadaweng \& P. B. Durst. 2007. Application of Assisted Natural Regeneration to Restore Degraded Tropical Forestlands. Restoration Ecology 15(4): 620-626. http://dx.doi.org/10.1111/ j.1526100X.2007.00274.X

Silva, W. R., M. A. Pizo \& V. A. Gabriel. 2010. Avifauna como promotora da restauração ecológica. In: S. Von- Matter, F.C. Straube, I. Accoerdi, V. Piacentini \& J. F. Cândido-Jr (eds.). Ornitologia e Conservação: Ciência Aplicada, Técnicas de Pesquisa e Levantamento, p. 507-516. Rio de Janeiro, Technical Books Editora.

Statsoft INC. 2004. Statistics for Windows (Software-system for data-analyses). Version 7.0. StatSoft Inc., Tulsa, Oklahoma, USA.

Telino-Júnior, W.R., M. M. Dias, S. M. D. A. Júnior, R. M. Lyra-Neves \& M. E. L. Larrazábal. 2005. Estrutura trófica da avifauna na Reserva Estadual de Gurjaú, Zona da Mata Sul, Pernambuco, Brasil. Revista Brasileira de Zoologia 22(4): 962-973. http://dx.doi.org/10.1590/ S010181752005000400024

Van-Andel, J. \& J. Aronson. 2012. Restoration Ecology: The New Frontier. Blackwell Science, Oxford.

Verdu, M. \& P. Garcia-Fayos. 1996. Nucleation Processes in a Mediterranean Birds-Dispersed Plant. Functional Ecology 10(2): 275-280. http://dx.doi.org/10.2307/2389853

Vicente, R., R. Martins, J. J. Zocche \& B. Harter-Marques. 2010. Seed dispersal by birds on artificial perches in reclaimed areas after surface coal mining in Siderópolis municipality, Santa Catarina State, Brazil. Revista Brasileira de Biociênicas 8(1): 14-23.

Vickery, J., N. Carter \& R. J. Fuller. 2002. The potential value of managed cereal field margins as foraging habitats for farmland birds in the UK. Agriculture, Ecosystems and Environment 89(1-2): 41-52.
Vielliard, J. M. E., M. E. C. Almeida, L. Anjos \& W. R. Silva. 2010. Levantamento quantitativo por pontos de escuta e o Índice Pontual de Abunância (IPA), p. 45-60. In: S. Von-Matter, F.C. Straube, I. Accoerdi, V. Piacentini \& J. F. Cândido-Jr (eds.). Technical Books Editora.

Vogel H. F., J. B. Campos \& F. C. Bechara. 2015. Early bird assemblages under different subtropical forest restoration strategies in Brazil: passive, nucleation and high diversity plantation. Tropical Conservation Science 8: 912-939.

Wal, H. V. H., B. Peña-Álvarez, S. L. Arriaga-Weiss \& S. Hernández-Daumás. 2012. Species, Functional Groups, and Habitat Preferences of Birds in Five Agroforestry Classes in Tabasco, Mexico. The Wilson Journal of Ornithology 124(3): 558-571. http:// dx.doi.org/10.1676/10-111.1

Willson, M. F. 1974. Avian Community Organization and Habitat Structure. Ecology 55(5):1017-1029. http://dx.doi. org/10.2307/1940352

Wright, S. J. 1980. Density Compensation in Island Avifaunas. Oecologia 45(3): 385-389. http://dx.doi.org/10.1007/BF00540211

Wunderle JR., J. M. 1997. The role of animal seed dispersal in accelerating native forest regeneration on degraded tropical lands. Forest Ecology and Management 99(1-2): 223235. http://dx.doi.org/10.1016/S03781127(97)00208-9

Yarranton, G.A. \& R. G. Morrison. 1974. Spatial Dynamics of a Primary Succession: Nucleation. The Journal of Ecology 62(2): 417428. http://dx.doi.org/10.2307/2258988

Zahawi, R. A., K. D. Holl, R. J. Cole \& J. L. Reid. 2013. Testing applied nucleation as a strategy to facilitate tropical forest recovery. Journal of Applied Ecology 51(1):88-96. 
Appendix 1. List of species. Values obtained by means of similarity of percentages (SIMPER) analysis carried out for the total dissimilarity between treatments and artificial groups. The guilds $(\alpha+\beta)$ use codes composed of diet (first letter) and main habitat (following two letters): insectivorous (I), omnivorous $(\mathrm{O})$, frugivorous $(\mathrm{F})$, granivorous $(\mathrm{G})$, nectarivorous $(\mathrm{N})$, carnivorous $(\mathrm{C})$; open area $(\mathrm{OA})$, forest $(\mathrm{FO})$, edge $(\mathrm{ED})$.

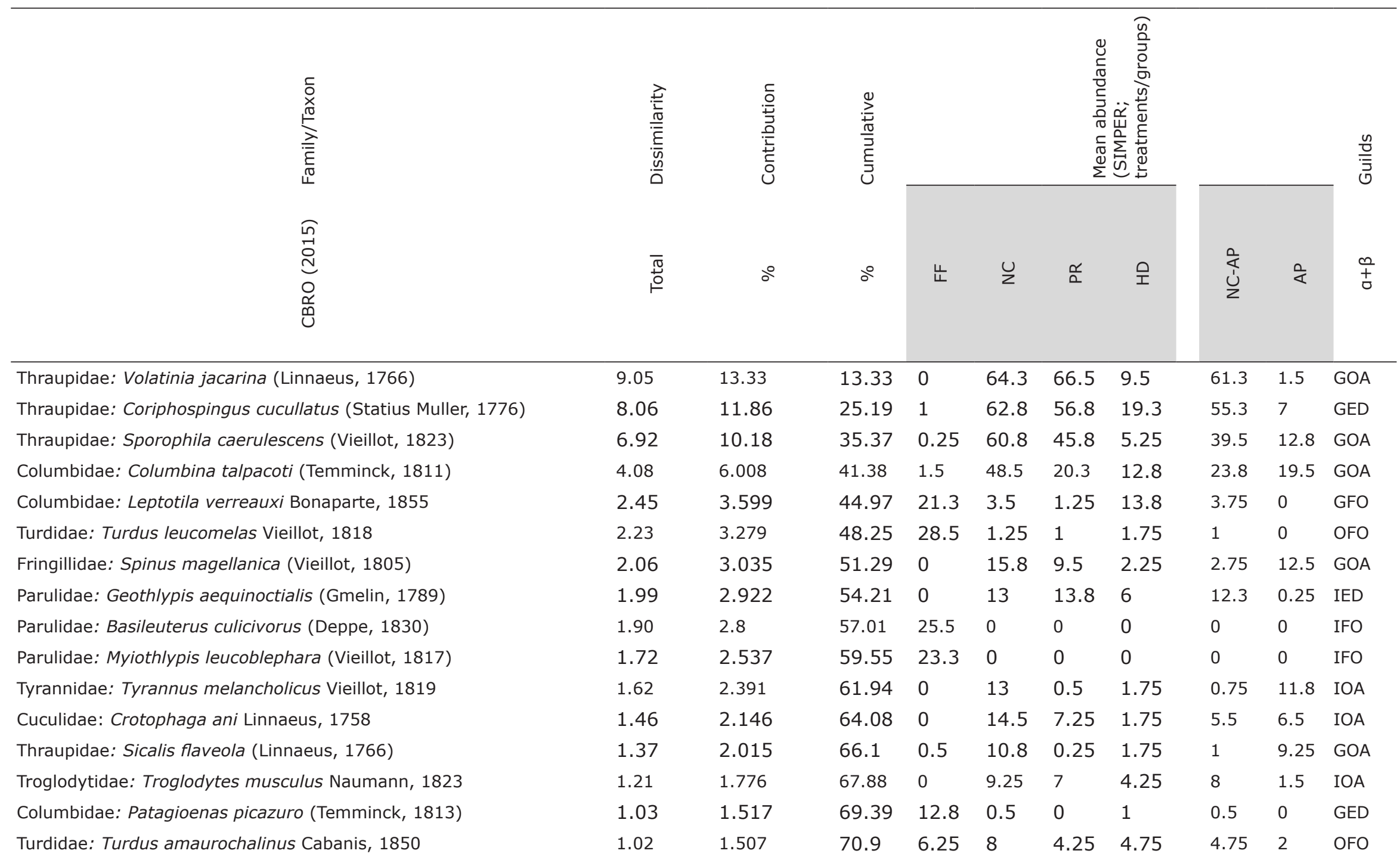


Parulidae: Setophaga pitiayumi (Vieillot, 1817)

Trochilidae: Chlorostilbon lucidus (Shaw, 1812)

Cardinalidae: Habia rubica (Vieillot, 1817)

Thraupidae: Embernagra platensis (Gmelin, 1789)

Thraupidae: Saltator similis d'Orbigny \& Lafresnaye, 1837

Tyrannidae: Tyrannus savana Vieillot, 1808

Tyrannidae: Pitangus sulphuratus (Linnaeus, 1766)

Furnariidae: Synallaxis spixi Sclater, 1856

Thraupidae: Tachyphonus coronatus (Vieillot, 1822)

Cuculidae: Guira guira (Gmelin, 1788)

Columbidae: Leptotila rufaxilla (Richard \& Bernard, 1792)

Turdidae: Turdus rufiventris Vieillot, 1818

Tyrannidae: Serpophaga subcristata (Vieillot, 1817)

Thraupidae: Conirostrum speciosum (Temminck, 1824)

Thraupidae: Trichothraupis melanops (Vieillot, 1818)

Furnariidae: Synallaxis cinerascens Temminck, 1823

Thamnophilidae: Thamnophilus ruficapillus Vieillot, 1816

Furnariidae: Lochmias nematura (Lichtenstein, 1823)

Tyrannidae: Lathrotriccus euleri (Cabanis, 1868)

Columbidae: Zenaida auriculata (Des Murs, 1847)

Icteridae: Agelaioides badius (Vieillot, 1819)

Momotidae: Baryphthengus ruficapillus (Vieillot, 1818)

Thraupidae: Tersina viridis (Illiger, 1811)

Thraupidae: Sicalis Iuteola (Sparrman, 1789)

Icteridae: Molothrus bonariensis (Gmelin, 1789)

Tyrannidae: Myiophobus fasciatus (Statius Muller, 1776)

Furnariidae: Furnarius rufus (Gmelin, 1788)

Trochilidae: Phaethornis pretrei (Lesson \& Delattre, 1839)

Tyrannidae: Myiodynastes maculatus (Statius Muller, 1776)

Mimidae: Mimus saturninus (Lichtenstein, 1823)

Cuculidae: Piaya cayana (Linnaeus, 1766)

Icteridae: Cacicus haemorrhous (Linnaeus, 1766)

\begin{tabular}{|c|c|c|c|c|c|c|c|c|c|}
\hline 0.98 & 1.441 & 72.34 & 13.5 & 0 & 0 & 0 & 0 & 0 & IFO \\
\hline 0.96 & 1.413 & 73.75 & 0.75 & 6.5 & 1.25 & 7.25 & 3 & 2.5 & NOA \\
\hline 0.93 & 1.366 & 75.12 & 12 & 0 & 0 & 0 & 0 & 0 & OFO \\
\hline 0.92 & 1.356 & 76.48 & 0 & 7 & 1.5 & 2.5 & 5.25 & 1.5 & GOA \\
\hline 0.92 & 1.353 & 77.83 & 7.5 & 5 & 4.75 & 0.75 & 5 & 0.5 & OFO \\
\hline 0.91 & 1.345 & 79.17 & 1.5 & 7.25 & 0.25 & 3.5 & 0.75 & 5.25 & IOA \\
\hline 0.88 & 1.289 & 80.46 & 5.25 & 7.25 & 1.75 & 1.75 & 1 & 4.75 & $\mathrm{OOA}$ \\
\hline 0.81 & 1.191 & 81.65 & 0 & 3.5 & 6.5 & 0.25 & 3.25 & 0 & IED \\
\hline 0.50 & 0.7329 & 82.39 & 2.5 & 2 & 3.25 & 0.5 & 2.25 & 0 & OFO \\
\hline 0.48 & 0.7025 & 83.09 & 0 & 0.25 & 1.5 & 3.25 & 0.25 & 0.5 & IOA \\
\hline 0.47 & 0.6982 & 83.79 & 6 & 0 & 0 & 0 & 0 & 0 & GFO \\
\hline 0.47 & 0.6897 & 84.48 & 4.5 & 0.5 & 0 & 1.5 & 0.25 & 0.25 & OFO \\
\hline 0.43 & 0.6297 & 85.11 & 0 & 2.5 & 3 & 1 & 2.25 & 0 & IOA \\
\hline 0.42 & 0.6164 & 85.72 & 3.75 & 0.5 & 1.25 & 0.5 & 0 & 0.5 & IFO \\
\hline 0.38 & 0.5628 & 86.29 & 5 & 0 & 0.25 & 0 & 0 & 0 & OFO \\
\hline 0.37 & 0.5474 & 86.83 & 5.25 & 0 & 0 & 0 & 0 & 0 & IED \\
\hline 0.37 & 0.5427 & 87.38 & 0.25 & 2.5 & 2.75 & 0.75 & 2.25 & 0 & IOA \\
\hline 0.35 & 0.5086 & 87.88 & 4.5 & 0 & 0 & 0 & 0 & 0 & IFO \\
\hline 0.34 & 0.5054 & 88.39 & 5 & 0 & 0 & 0 & 0 & 0 & IFO \\
\hline 0.33 & 0.4893 & 88.88 & 0.5 & 2.75 & 0.5 & 0.5 & 0.25 & 2.25 & GOA \\
\hline 0.32 & 0.4751 & 89.35 & 0 & 2.75 & 0 & 0 & 2 & 0.75 & GOA \\
\hline 0.30 & 0.4465 & 89.8 & 3.75 & 0 & 0 & 0 & 0 & 0 & IFO \\
\hline 0.29 & 0.4248 & 90.23 & 2 & 0.25 & 0 & 1.25 & 0 & 0 & FED \\
\hline 0.28 & 0.4053 & 90.63 & 0 & 1 & 1.75 & 1 & 1 & 0.25 & GOA \\
\hline 0.27 & 0.3945 & 91.03 & 0 & 2 & 0.5 & 0 & 0.25 & 1.75 & GOA \\
\hline 0.26 & 0.384 & 91.41 & 0.25 & 1.75 & 1.5 & 0 & 1.5 & 0 & IOA \\
\hline 0.26 & 0.3836 & 91.79 & 0 & 1.75 & 1 & 0 & 0.25 & 1.5 & IOA \\
\hline 0.26 & 0.3786 & 92.17 & 3.25 & 0 & 0.25 & 0 & 0 & 0 & NED \\
\hline 0.24 & 0.3585 & 92.53 & 3.5 & 0 & 0 & 0 & 0 & 0 & IFO \\
\hline 0.24 & 0.3488 & 92.88 & 0 & 1 & 0 & 0.25 & 0 & 2 & OOA \\
\hline 0.22 & 0.3287 & 93.21 & 3 & 0 & 0 & 0 & 0 & 0 & IED \\
\hline 0.22 & 0.3218 & 93.53 & 3 & 0 & 0 & 0 & 0 & 0 & \\
\hline
\end{tabular}


Turdidae: Turdus albicollis Vieillot, 1818

Accipitridae: Rupornis magnirostris (Gmelin, 1788)

Passerellidae: Ammodramus humeralis (Bosc, 1792)

Thraupidae: Tangara sayaca (Linnaeus, 1766)

Rynchocyclidae: Leptopogon amaurocephalus Tschudi, 1846

Tyrannidae: Elaenia flavogaster (Thunberg, 1822)

Rynchocyclidae: Myiornis auriculares (Vieillot, 1818)

Furnariidae: Synallaxis ruficapilla Vieillot, 1819

Accipitridae: Elanus leucurus (Vieillot, 1818)

Cardinalidae: Cyanoloxia brissonii (Lichtenstein, 1823)

Picidae: Colaptes melanochloros (Gmelin, 1788)

Tyrannidae: Empidonomus varius (Vieillot, 1818)

Hirundinidae: Progne tapera (Vieillot, 1817)

Tyrannidae: Camptostoma obsoletum (Temminck, 1824)

Rynchocyclidae: Phylloscartes ventralis (Temminck, 1824)

Tyrannidae: Megarynchus pitangua (Linnaeus, 1766)

Cracidae: Penelope superciliaris Temminck, 1815

Rallidae: Aramides saracura (Spix, 1825)

Thraupidae: Pipraeidea melanonota (Vieillot, 1819)

Thamnophilidae: Thamnophilus caerulescens Vieillot, 1816

Picidae: Picumnus temminckii Lafresnaye, 1845

Trogonidae: Trogon surrucura Vieillot, 1817

Tyrannidae: Euscarthmus meloryphus Wied, 1831

Cuculidae: Coccyzus melacoryphus Vieillot, 1817

Corvidae: Cyanocorax chrysops (Vieillot, 1818)

Cuculidae: Tapera naevia (Linnaeus, 1766)

Turdidae: Turdus subalaris (Seebohm, 1887)

Cardinalidae: Cyanoloxia glaucocaerulea

(d'Orbigny \& Lafresnaye, 1837)

Tinamidae: Crypturellus parvirostris (Wagler, 1827)

Caprimulgidae: Hydropsalis albicollis (Gmelin, 1789)

Conopophagidae: Conopophaga lineata (Wied, 1831)

Strigidae: Athene cunicularia Molina, 1782)

\begin{tabular}{|c|c|c|c|c|c|c|c|c|c|}
\hline 0.22 & 0.3176 & 93.85 & 2.75 & 0 & 0 & 0 & 0 & 0 & OFO \\
\hline 0.21 & 0.3154 & 94.16 & 1.5 & 1 & 0.25 & 0 & 0 & 1 & COA \\
\hline 0.20 & 0.3009 & 94.46 & 0 & 2 & 0 & 0 & 1.75 & 0 & GOA \\
\hline 0.20 & 0.2928 & 94.76 & 1.25 & 1 & 0.25 & 0 & 0.75 & 0.25 & OFO \\
\hline 0.20 & 0.2875 & 95.04 & 2.75 & 0 & 0 & 0 & 0 & 0 & IFO \\
\hline 0.18 & 0.2634 & 95.31 & 0 & 1.5 & 0 & 0.5 & 1 & 0.25 & OED \\
\hline 0.18 & 0.2607 & 95.57 & 0 & 0.5 & 1.75 & 0 & 0.5 & 0 & IED \\
\hline 0.17 & 0.2547 & 95.82 & 2.25 & 0 & 0 & 0 & 0 & 0 & IED \\
\hline 0.17 & 0.2533 & 96.08 & 0 & 1 & 0 & 0.5 & 0.25 & 0.75 & $\mathrm{COA}$ \\
\hline 0.17 & 0.2502 & 96.33 & 0 & 0.5 & 1.25 & 0.25 & 0.75 & 0 & GOA \\
\hline 0.17 & 0.2496 & 96.58 & 0 & 0.25 & 0 & 1.5 & 0 & 0.25 & IED \\
\hline 0.16 & 0.2303 & 96.81 & 0.25 & 1 & 0 & 0 & 0 & 1 & IOA \\
\hline 0.15 & 0.2207 & 97.03 & 0 & 0.75 & 0.5 & 0.5 & 0.75 & 0 & IOA \\
\hline 0.15 & 0.2138 & 97.24 & 0.5 & 1 & 0.5 & 0 & 0.5 & 0 & IOA \\
\hline 0.14 & 0.2017 & 97.44 & 1.75 & 0 & 0 & 0 & 0 & 0 & IFO \\
\hline 0.13 & 0.1976 & 97.64 & 1 & 0.5 & 0 & 0 & 0 & 0.5 & OED \\
\hline 0.13 & 0.1893 & 97.83 & 2 & 0 & 0 & 0 & 0 & 0 & OFO \\
\hline 0.12 & 0.1782 & 98.01 & 1.25 & 0 & 0 & 0.25 & 0 & 0 & OFO \\
\hline 0.11 & 0.1692 & 98.18 & 1.5 & 0 & 0 & 0 & 0 & 0 & OFO \\
\hline 0.11 & 0.1686 & 98.34 & 1.75 & 0 & 0 & 0 & 0 & 0 & IFO \\
\hline 0.11 & 0.168 & 98.51 & 1.25 & 0 & 0.5 & 0 & 0 & 0 & IED \\
\hline 0.10 & 0.1504 & 98.66 & 1.25 & 0 & 0 & 0 & 0 & 0 & OFO \\
\hline 0.10 & 0.1407 & 98.8 & 1.25 & 0 & 0 & 0 & 0 & 0 & IFO \\
\hline 0.09 & 0.1256 & 98.93 & 0 & 0.25 & 0 & 0.5 & 0.25 & 0 & IED \\
\hline 0.08 & 0.1241 & 99.05 & 1.25 & 0 & 0 & 0 & 0 & 0 & OED \\
\hline 0.08 & 0.1214 & 99.17 & 0.25 & 0 & 1 & 0 & 0 & 0 & IED \\
\hline 0.08 & 0.12 & 99.29 & 1 & 0 & 0 & 0 & 0 & 0 & OFO \\
\hline 0.07 & 0.1063 & 99.4 & 1 & 0 & 0 & 0 & 0 & 0 & GED \\
\hline 0.07 & 0.1057 & 99.51 & 0.5 & 0.25 & 0 & 0.25 & 0.25 & 0 & OFO \\
\hline 0.07 & 0.1009 & 99.61 & 0 & 0 & 0 & 0.75 & 0 & 0 & IED \\
\hline 0.06 & 0.09466 & 99.7 & 1 & 0 & 0 & 0 & 0 & 0 & IFO \\
\hline 0.05 & 0.06822 & 99.77 & 0 & 0 & 0 & 0.5 & 0 & 0 & $\mathrm{COA}$ \\
\hline
\end{tabular}


Falconidae: Milvago chimachima (Vieillot, 1816)

Thraupidae: Sporophila nigricollis (Vieillot, 1823)

Pipridae: Chiroxiphia caudata (Shaw \& Nodder, 1793)

Picidae: Veniliornis spilogaster (Wagler, 1827)

Thamnophilidae: Mackenziaena leachii (Such, 1825)

Ramphastidae: Pteroglossus castanotis Gould, 1834

Cathartidae: Coragyps atratus (Bechstein, 1793)

Tyrannidae: Satrapa icterophrys (Vieillot, 1818)

\begin{tabular}{|c|c|c|c|c|c|c|c|c|c|c|}
\hline $31 / 88$ & 67.93 & $100 \%$ & $100 \%$ & 993 & 1582 & 1097 & 467 & 1131 & 451 & 14 \\
\hline Families/Species & $\begin{array}{l}\text { Dissimi- } \\
\text { larity }\end{array}$ & Total & Total & Tota & f Cont & cts & & & & Guilds \\
\hline
\end{tabular}


Annex 1 (supplementary document 1). List of species used for the implementation of high-diversity planting (HD) and nucleation (NC) techniques. The nomenclature adopted for families and genera follow the Angiosperm Phylogeny Group III pattern [1]. Species identification (epithets) follows the List of Flora of Brazil, 2013 [2] and The International Plant Names Index, 2013 [3]. CT-SU means guilds: pioneer (P) and non-pioneer (NP), while CT-SI means silvicultural category based on NBL and TNC [4].

\begin{tabular}{|c|c|c|c|c|}
\hline Code & Family & Species & CT-SU & CT-SI \\
\hline 1 & Euphorbiaceae & Croton floribundus Spreng. & $\mathrm{P}$ & Filling \\
\hline 2 & Fabaceae & Mimosa scabrella Benth. & $\mathrm{P}$ & Filling \\
\hline 3 & Primulaceae & Myrsine coriaceae (Sw.) R. Br & $\mathrm{P}$ & diversity \\
\hline 4 & Myrtaceae & Psidium cf. cattleyanum (Mart. ex O. Berg) Kiaersk. & NP & diversity \\
\hline 5 & Phytolaccaceae & Gallesia integrifolia (Spreng.) Harms & NP & diversity \\
\hline 6 & Myrtaceae & Myrcianthes pungens (O.Berg) D.Legrand & NP & diversity \\
\hline 7 & Aquifoliaceae & Ilex paraguariensis A.St.-Hil. & NP & diversity \\
\hline 8 & Laminaceae & Vitex megapotamica (Spreng.) Moldenke & NP & diversity \\
\hline 11 & Cannabaceae & Trema micrantha (L.) Blume & $P$ & filling \\
\hline 12 & Annonaceae & Annona cacans Warm. & $\mathrm{P}$ & diversity \\
\hline 15 & Caricaceae & Jaracatia spinosa (Aubl.) DC. & NP & diversity \\
\hline 16 & Euphorbiaceae & cf. Croton urucurana Baill. & $P$ & diversity \\
\hline 18 & Sterculiaceae & Guazuma ulmifolia Lam. & $P$ & filling \\
\hline 19 & Fabaceae & Piptadenia gonoacantha (Mart.) J.F. Macbr. & NP & filling \\
\hline 23 & Loganiaceae & Strychnos brasiliensis (Spreng.) Mart. & NP & diversity \\
\hline 24 & Fabaceae & Machaerium stipitatum (DC.) Vogel & NP & diversity \\
\hline 25 & Rosaceae & Prunus myrtifolia (L.) Urb. & NP & diversity \\
\hline 26 & Rubiaceae & Randia ferox (Cham. \& Schltdl.) DC. & $\mathrm{P}$ & diversity \\
\hline 27 & Sapindaceae & Allophyllus edulis (A.St.-Hil., Cambess. \& A. Juss.) Radlk. & $\mathrm{P}$ & diversity \\
\hline 28 & Fabaceae & Cassia leptophylla Vogel. & NP & diversity \\
\hline 29 & Lauraceae & Ocotea porosa (Nees) Barroso & NP & diversity \\
\hline 30 & Elaeocarpaceae & Sloanea monosperma Vell. & NP & diversity \\
\hline 31 & Cannabaceae & Celtis cf. iguanaea (Jacq.) Sargent & $\mathrm{P}$ & diversity \\
\hline 32 & Lythraceae & Lafoensia pacari A.St.-Hil & NP & diversity \\
\hline 33 & Primulaceae & Myrsine umbellata Mart. & NP & diversity \\
\hline 34 & Euphorbiaceae & Alchornea sidifolia Müll.Arg. & NP & filling \\
\hline 35 & Myrtaceae & Campomanesia xanthocarpa O.Berg & NP & diversity \\
\hline 36 & Fabaceae & Inga vera Willd. & NP & diversity \\
\hline 37 & Bignoniaceae & Jacaranda micrantha Cham. & NP & diversity \\
\hline 38 & Asteraceae & Moquiniastrum polymorpha (Less.) Cabr. & $\mathrm{P}$ & diversity \\
\hline 39 & Meliaceae & Cabralea canjarana (Vell) Mart & NP & diversity \\
\hline 40 & Lauraceae & Ocotea puberula (Rich.) Ness & NP & diversity \\
\hline 41 & Fabaceae & Calliandra tweedii Benth. & $P$ & diversity \\
\hline 42 & Podocarpaceae & Podocarpus lambertii Klotzsch & $\mathrm{T}$ & diversity \\
\hline 44 & Canellaceae & Cinnamodendron dinisii Schwacke & NP & diversity \\
\hline 45 & Salicaceae & Xylosma sp. & $P$ & diversity \\
\hline 47 & Euphorbiaceae & Sebastiania commersoniana (Baill.) L.B. Sm. \& Downs & $P$ & diversity \\
\hline 48 & Boraginaceae & Cordia americana (L.) Gottshling \& J.E.Mill. & NP & diversity \\
\hline
\end{tabular}




\begin{tabular}{|c|c|c|c|c|}
\hline 50 & Euphorbiaceae & Sebastiania schottiana (Müll.Arg.) Müll.Arg. & NP & diversity \\
\hline 53 & Myrtaceae & Campomanesia guazumifolia (Cambess.) O.Berg. & NP & diversity \\
\hline 54 & Sapindaceae & Cupania vernalis Cambess. & NP & diversity \\
\hline 55 & Meliaceae & Cedrela fissilis Vellozo & NP & diversity \\
\hline 56 & Malvaceae & Ceiba speciosa (A. St.-Hil.) Ravenna & NP & diversity \\
\hline 57 & Bignoniaceae & Handroanthus chrysotrichus (Mart. ex A.DC.) Mattos & NP & diversity \\
\hline 58 & Rutaceae & Zanthoxylum rhoifolium Lam. & NP & diversity \\
\hline 58 & Rutaceae & Balfourodendron riedelianum (Engl.) Engl. & NP & diversity \\
\hline 59 & Anacardiaceae & Schinus terebinthifolius Raddi & $\mathrm{P}$ & filling \\
\hline 60 & Moraceae & Ficus enormis (Mart. ex Miq.) Mart. & $\mathrm{P}$ & diversity \\
\hline 63 & Fabaceae & Peltophorum dubium (Spreng.) Taub. & $\mathrm{P}$ & diversity \\
\hline 64 & Fabaceae & Lonchocarpus sp. & - & diversity \\
\hline 66 & Sapindaceae & Diatenopteryx sorbifolia Radlk. & $\mathrm{P}$ & diversity \\
\hline 67 & Fabaceae & Erythrina falcata Benth. & NP & diversity \\
\hline 68 & Fabaceae & Bauhinia forficata Link & NP & filling \\
\hline 69 & Salicaceae & Casearia decandra Jacq. & NP & diversity \\
\hline 72 & Meliaceae & Trichilia claussenii C. DC. & NP & diversity \\
\hline 73 & Myrtaceae & cf. Myrceugenia euosma (O.Berg) D. Legrand & NP & diversity \\
\hline 74 & Myrtaceae & Eugenia pyriformis Cambess. & NP & diversity \\
\hline 75 & Myrtaceae & Eugenia uniflora L. & NP & diversity \\
\hline 76 & Myrtaceae & Eugenia involucrata DC. & NP & diversity \\
\hline 77 & Myrtaceae & Plinia peruviana (Poir.) Govaerts & NP & diversity \\
\hline 79 & Solanaceae & Solanum cf. bullatum Vell. & $\mathrm{P}$ & filling \\
\hline 101 & Apocynaceae & Aspidosperma polyneuron Müll.Arg. & NP & diversity \\
\hline 103 & Fabaceae & Albizia polycephala (Benth.) Killip & $\mathrm{P}$ & diversity \\
\hline 104 & Araucariaceae & Araucaria angustifolia (Bertol.) Kuntze & NP & diversity \\
\hline 110 & Fabaceae & Parapiptadenia rigida (Benth.) Brenan & NP & diversity \\
\hline 120 & Fabaceae & Mimosa bimucronata (DC.) Kuntze & $\mathrm{P}$ & diversity \\
\hline 121 & Arecaceae & Butia capitata (Mart.) Becc. & NP & diversity \\
\hline 122 & Celastraceae & Maytenus aquifolia Mart. & NP & diversity \\
\hline 123 & Polygonaceae & Ruprechtia laxiflora Meisn. & NP & diversity \\
\hline 124 & Arecaceae & Syagrus romanzoffiana (Cham.) Glassman & NP & diversity \\
\hline 125 & Fabaceae & Enterolobium contortisiliquum (Vell.) Morong & NP & filling \\
\hline
\end{tabular}

References: [1] APG III. 2009. The angiosperm phylogeny group III. An update of the angiosperm phylogeny group classification for the orders and families of higher plants: APG III. Botanical Journal of the Linnean Society 161:105-121. [2] Lista de Espécies da Flora do Brasil. 2012. Jardim Botânico do Rio de Janeiro. Available at: <http://floradobrasil.jbrj.gov.br/>. Accessed 26 May 2014. [3] The International Plant Names Index. 2013. Published on the Internet http://www.ipni.org. Accessed 1 May 2013. [4] NBL \& TNC. 2013. Manual de Restauração Florestal: Um Instrumento de Apoio à Adequação Ambiental de Propriedades Rurais do Pará. The Nature Conservancy, Belém, PA. 128 pages. Available at http://www.nature.org/media/brasil/manual-de-restauracao-florestal.pdf. Accessed 26 May 2014. 